\title{
Adverse Cardiovascular Effects of Anti-COVID-19 Drugs
}

\author{
Dongling Liu ${ }^{1 * t}$, Xiang Zeng ${ }^{2 \dagger}$, Zufeng Ding ${ }^{3}$, Fenghua Lv ${ }^{4}$, Jawahar L. Mehta ${ }^{3}$ and \\ Xianwei Wang ${ }^{1,4 *}$
}

${ }^{1}$ Henan Key Laboratory of Medical Tissue Regeneration, Xinxiang Medical University, Xinxiang, China, ${ }^{2}$ Laboratory of Environmental Medicine and Developmental Toxicology, Guangdong Key Laboratory of Environmental Pollution and Health, School of Environment, Jinan University, Guangzhou, China, ${ }^{3}$ Division of Cardiology, University of Arkansas for Medical Sciences and Central Arkansas Veterans Healthcare System, Little Rock, AR, United States, ${ }^{4}$ Department of Cardiology, Xinxiang Medical University First Affiliated Hospital, Weihui, China

OPEN ACCESS

Edited by:

Tao Xu,

Anhui Medical University, China

Reviewed by:

Georgina May Ellison-Hughes,

King's College London,

United Kingdom

Stefano Carugo,

IRCCS Ca' Granda Foundation

Maggiore Policlinico Hospital, Italy

*Correspondence:

Xianwei Wang

161042@xxmu.edu.cn

Dongling Liu

liudongling@xxmu.edu.cn

${ }^{\dagger}$ These authors have contributed equally to this work and share first

authorship

Specialty section:

This article was submitted to Inflammation Pharmacology,

a section of the journal

Frontiers in Pharmacology

Received: 24 April 2021 Accepted: 13 August 2021

Published: 25 August 2021

Citation:

Liu D, Zeng X, Ding Z, Lv F, Mehta JL and Wang $X$ (2021) Adverse Cardiovascular Effects of Anti-COVID-

19 Drugs.

Front. Pharmacol. 12:699949. doi: 10.3389/fphar.2021.699949
Severe acute respiratory syndrome coronavirus 2 (SARS-CoV-2) or COVID-19 infection is the cause of the ongoing global pandemic. Mortality from COVID-19 infection is particularly high in patients with cardiovascular diseases. In addition, COVID-19 patients with preexisting cardiovascular comorbidities have a higher risk of death. Main cardiovascular complications of COVID-19 are myocardial infarction, myocarditis, acute myocardial injury, arrhythmias, heart failure, stroke, and venous thromboembolism. Therapeutic interventions in terms of drugs for COVID-19 have many cardiac adverse effects. Here, we review the relative therapeutic efficacy and adverse effects of anti-COVID-19 drugs.

Keywords: COVID-19, SARS-CoV-2, anti-COVID-19 therapy, cardiovascular complications, inflammation

\section{INTRODUCTION}

Coronavirus disease 2019 (COVID-19) is a current global, emerging, and pandemic respiratory disease caused by an infection of SARS-CoV-2 (Huang et al., 2020). SARS-CoV-2 is a kind of RNA virus with a characteristic envelope and a linear single positive strand genome, which is different from severe acute respiratory syndrome (SARS) and Middle East respiratory syndrome (MERS) in infectivity and gene structure (Chen et al., 2020; Rabaan et al., 2020; Shereen et al., 2020). So far, there were more than 183 million documented global cases of COVID-19 and 4 million deaths according to reports of the World Health Organization (WHO) and Johns Hopkins University (Johns Hopkins University, 2021; WHO, 2021). In other words, the global pandemic of COVID-19 infection is still serious, although vaccines from different countries and companies have been used worldwide (Dong et al., 2020; Kissler et al., 2020; Zhang et al., 2020a). Therefore, it is necessary to discuss the adverse effects of different therapies.

So far, the main anti-COVID-19 therapies are drug treatments. However, there are few effective drugs, and cardiovascular complications of drugs and SARS-CoV-2 mutation make it harder for potential drugs to effectively control the COVID-19 pandemic (Hamid et al., 2020).

COVID-19 is more than just a lung disease, and cardiovascular complications are common and serious in patients with COVID-19 (Bikdeli et al., 2020; Lala et al., 2020; Lang et al., 2020; Li et al., 2020; Liu et al., 2020d; Madjid et al., 2020). COVID-19 patients with cardiovascular and respiratory

Abbreviations: ACE2, angiotensin-converting enzyme 2; CVD, Cardiovascular diseases; COVID-19, Coronavirus disease 2019, CQ, chloroquine; ECG, electrocardiogram; FDA, Food and Drug Administration; HCQ, hydroxychloroquine; HIV, human immunodeficiency virus; IFN- $\alpha$, Interferon- $\alpha$; MERS, Middle East respiratory syndrome; NHC, National Health Commission of the People's Republic of China; PCQ, chloroquine phosphate; SARS, severe acute respiratory syndrome; SARS-CoV-2, Severe acute respiratory syndrome coronavirus 2; TCM, traditional Chinese medicine; WHO, World Health Organization. 

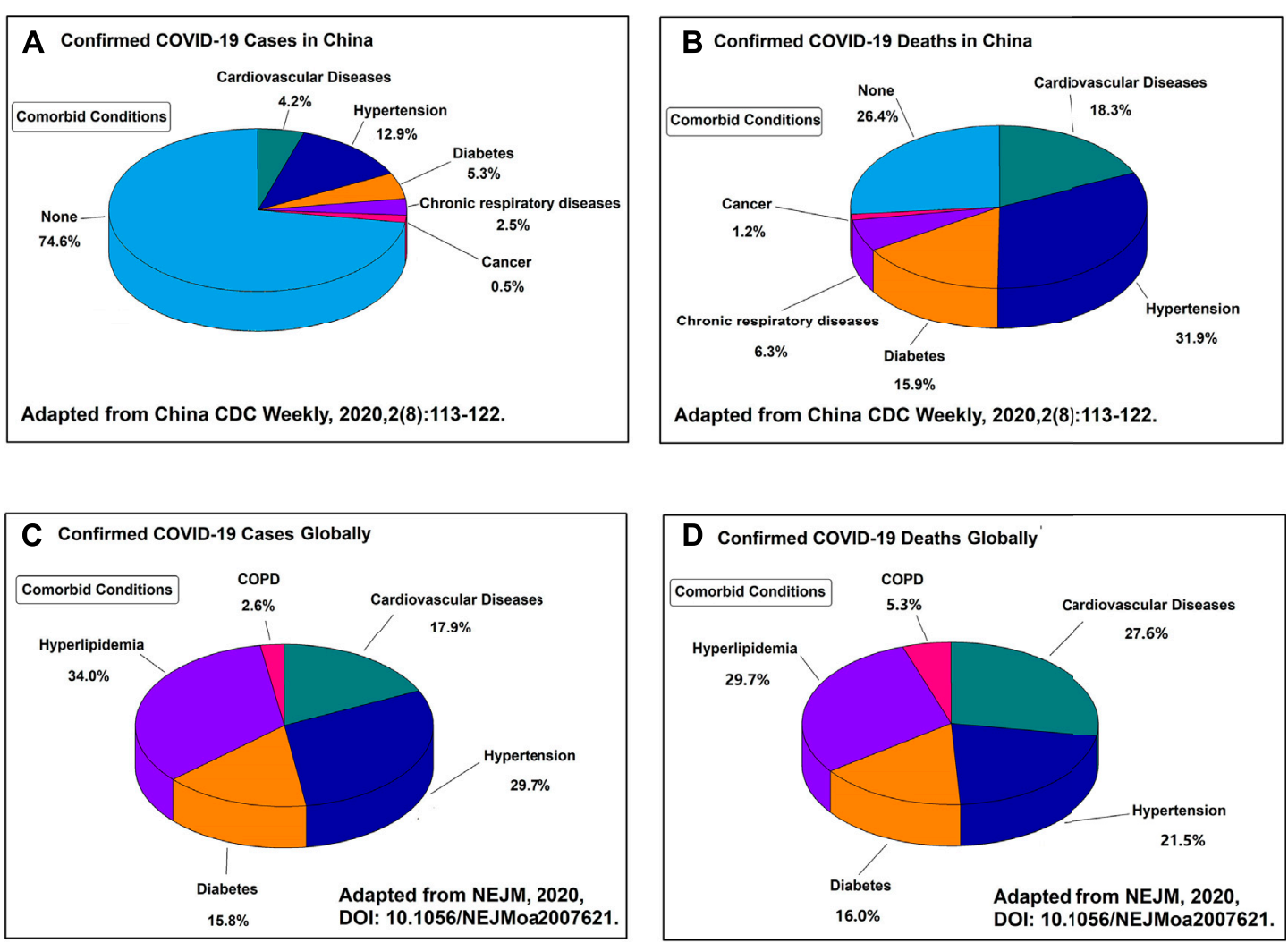

FIGURE 1 | (A) Proportion of the Chinese patients and their comorbid conditions that were diagnosed with COVID-19. (B) Proportion of the Chinese patients and their comorbid conditions that died from COVID-19. (C) Proportion of the global patients and their comorbid conditions that were diagnosed with COVID-19. (D) Proportion of the global patients and their comorbid conditions that died from COVID-19. All the four figures indicate that the major complications of COVID-19 are the cardiovascular related diseases.

comorbidities contribute to the highest case fatality rate (Figure 1) (CDC, 2020a; Clerkin et al., 2020; Giustino et al., 2020; Kunutsor and Laukkanen, 2020; Li et al., 2020a; Qiu et al., 2020). Cardiovascular disease patients are more susceptible to SARS-CoV-2 and more likely to develop severe COVID-19 (Akhmerov and Marbán, 2020; Chung et al., 2020; Driggin et al., 2020; Han, 2020; Katz et al., 2020; Mahmud et al., 2020). In particular, children with COVID-19 have also been reported to develop hyperinflammatory shock with characteristics similar to Kawasaki disease, including abnormalities of the coronary vessels and cardiac dysfunction (Akca et al., 2020; Alizargar, 2020; Toubiana et al., 2020). Common cardiovascular complications of COVID-19 are arrhythmias, direct cardiac injury, fulminant myocarditis, acute myocardial infarction, heart failure, pulmonary embolism, and disseminated intravascular coagulation (Aid et al., 2020; Barison et al., 2020; Guzik et al., 2020; Long et al., 2020; Maleszewski et al., 2020; Matsushita et al., 2020). Cytokine storm is associated with the severity and mortality of COVID-19 patients, which may be regulated by a key inflammation regulator known as the NLRP3 inflammasome (Liu et al., 2018; Liu et al., 2020a; Ruscitti et al., 2020; Ye et al., 2020). Excess activation of NLRP3 inflammasome increases the cardiovascular complication in COVID-19 patients (Bertocchi et al., 2020; Freeman and
Swartz, 2020; Paniri and Akhavan-Niaki, 2020). However, to date, little is known about the cardiovascular complications of anti-COVID-19 drug therapy.

Current common anti-COVID-19 therapies include antiviral treatment, immunotherapy, convalescent plasma, traditional Chinese medicine, oxygen therapy, nutritional support, mechanical ventilation, and nursing care (CDC, 2020b; Inglis et al., 2020; Zhang, 2020g; Nih, 2021; Yetman and Vinetz, 2021). It is important to understand in-depth the cardiovascular complications of anti-COVID-19 therapy to further define the benefit of drug treatment strategies. Here, we summarize the cardiovascular complications of anti-COVID-19 drugs and discuss the performance of various treatment options to shed light on drug therapies for COVID-19.

\section{MECHANISMS OF CARDIOVASCULAR COMPLICATIONS OF COVID-19}

The interplay between cardiovascular disease (CVD) and COVID19 may manifest itself in three patterns: 1 ) CVD increases mortality among COVID-19 patients; 2) SARS-CoV-2 infection causes new CVD; 3) Drugs for CVD patients interfere with the physiology, pathophysiology and pharmacology of COVID-19 and vice versa 


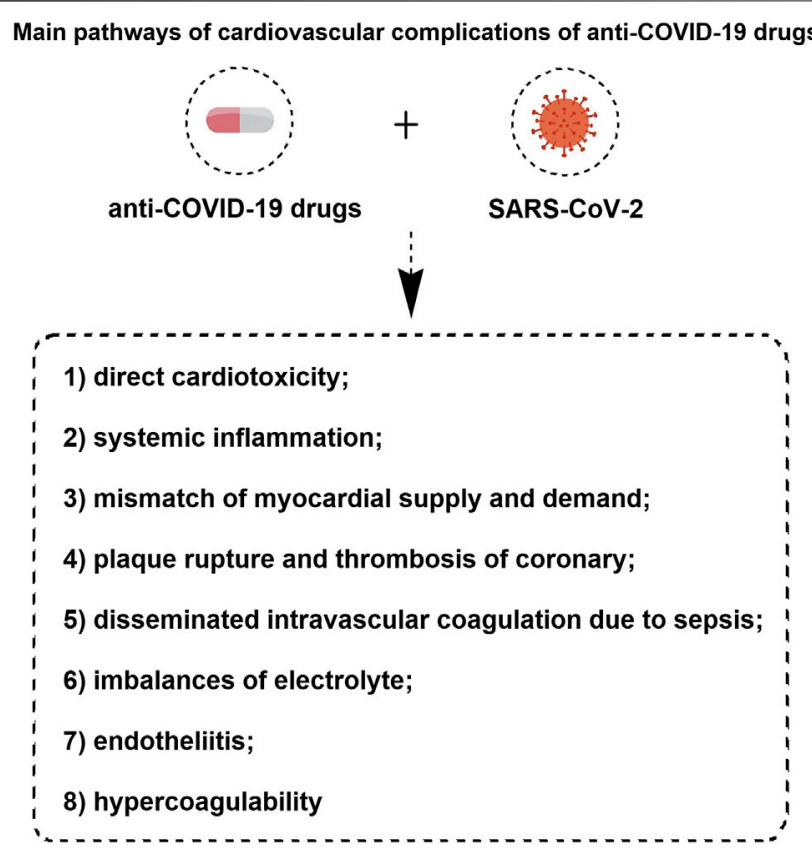

FIGURE 2 | The main pathways of cardiovascular complications of antiCOVID-19 drugs.

(Ferrari et al., 2020). The mechanisms for the cardiovascular complications of COVID-19 are still not fully understood. However, the main pathways of cardiovascular complications of anti-COVID-19 drugs have been proposed are listed as follows (Figure 2): 1) direct cardiotoxicity; 2) systemic inflammation; 3) mismatch of myocardial supply and demand; 4) plaque rupture and thrombosis of coronary; 5) disseminated intravascular coagulation due to sepsis; 6) imbalances of electrolyte; 7) endotheliitis and 8) hypercoagulability (Bansal, 2020; Kang et al., 2020; Nishiga et al., 2020; Nägele et al., 2020; Varga et al., 2020).

There is a common consensus that receptor-mediated endocytosis is the main way for the virus to enter cells. Up to now, a well-known molecular mechanism of COVID-19 is that SARS-CoV-2 can directly or indirectly invade humans by binding to angiotensin converting enzyme 2 [ACE2, an important component of the renin-angiotensin-aldosterone system (RAS)], which can lead to alterations in the ACE2 signaling pathway and subsequently induce lung and myocardial injury (Figure 3) (Liu et al., 2020g; Brojakowska et al., 2020; Sharma, 2020; Wang et al., 2020b; Wang et al., 2020d; Zheng et al., 2020; Zhou et al., 2020). The interaction of SARS-CoV-2 with RAS leads to electrolyte imbalance and results in hypokalemia (Lumpuy-Castillo et al., 2020). As RAS inhibitors, angiotensin converting enzyme inhibitors (ACEIs), angiotensin receptor blockers (ARBs), and statins were used to decrease the risk of COVID-19 infection or severity by improving endothelial dysfunction (Liu et al., 2020f; De Spiegeleer et al., 2020; Lee et al., 2020; Nägele et al., 2020). Although some studies challenged ACEIs/ARBs/statin therapy for COVID-19, ACEIs/ARBs/statin treatment should continue in patients with COVID-19 based on available reported evidence (Liu et al., 2020d; Fosbol et al., 2020; Hasan et al., 2020; Mehta et al., 2020; Zhang et al., 2020d; Zhang et al., 2020e; Tetlow et al., 2021).

The most severe cases of COVID-19 are characterized by an acute systemic inflammatory response, cytokine storm, endotheliitis, and hypercoagulability. Systemic infection, coupled with hypoxia, can lead to imbalance/mismatch of the myocardial supply and demand ratio. Increased of systemic inflammation and shear stress due to elevated coronary blood flow causes plaque rupture and subsequent arrhythmias, acute myocardial infarction, and heart failure. It is well known that endothelial cells play a crucial role in the maintenance and regulation of vascular homeostasis and coagulation. Endodermatitis, characterized by endothelial dysfunction and hypercoagulability, is a common feature of major comorbidities that increase the risk of severe COVID-19 (Becker, 2020; Fan et al., 2020; Panigada et al., 2020).

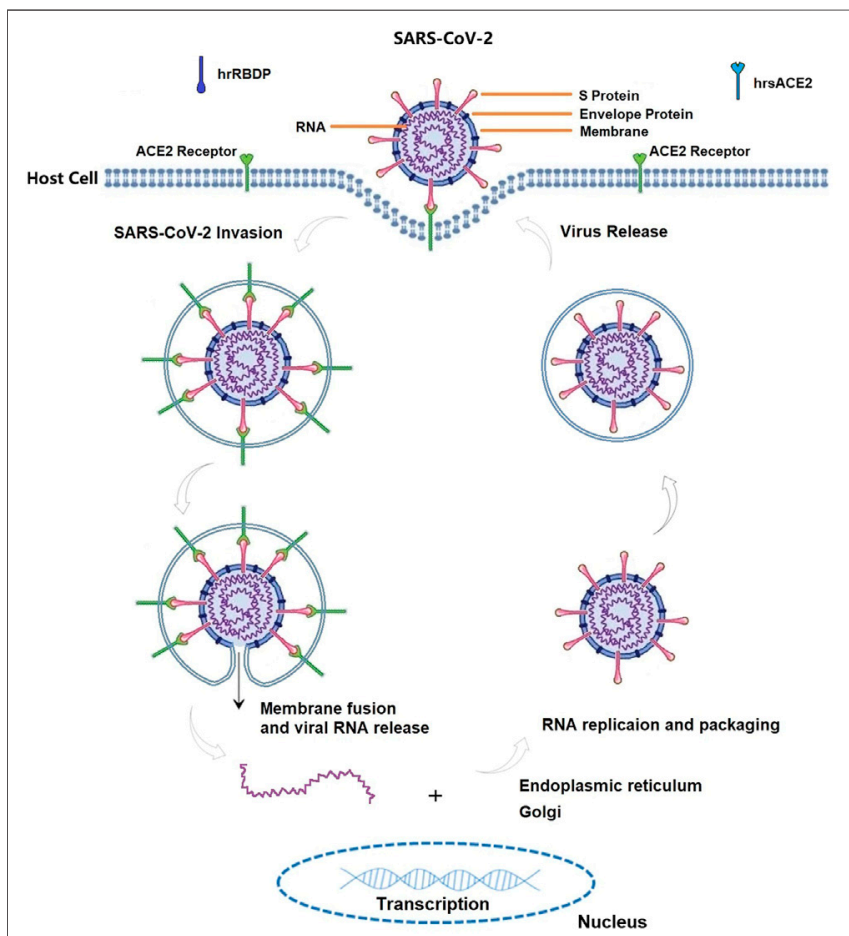

FIGURE 3 | The life cycle of SARS-CoV-2 in host cells, annotated with the known mechanisms by ACE2 biology pathway. ACE2 can be recognized by the spike (S) protein on the surface of SARS-CoV-2, and their combination enable the virus to enter human cells in term of attachment, fusion and entry. S protein compose of S1 subunit (containing receptor-binding domain (RBD) which can bind to host receptor) and S2 subunit (fusing the viral and host membranes). Therefore, both ACE2 and S protein can serve as targets for the development of entry inhibitors, antibodies, and vaccines. Any substances modifying ACE2-S protein complex are valid targets for antiCOVID-19 agents. For instances, human recombinant soluble ACE2 (hrsACE2, its structure similar with ACE2) and recombinant RBD protein (hrRBDP, its structure similar with $S$ protein) are competitively binding to $S$ protein and ACE2 receptor, which ultimately participate in the fight against COVID-19. 
TABLE 1 | Antiviral and anti-inflammatory drugs that have been suggested for the treatment of COVID-19 infection.

\begin{tabular}{|c|c|c|c|c|c|c|c|}
\hline $\begin{array}{l}\text { Antiviral and } \\
\text { anti- } \\
\text { inflammatory } \\
\text { drugs }\end{array}$ & $\begin{array}{l}\text { Targeted } \\
\text { virions }\end{array}$ & Mechanism & $\begin{array}{c}\text { Total } \\
\text { direction } \\
\text { of effect }\end{array}$ & $\begin{array}{l}\text { Pharmacokinetic } \\
\text { role (inhibitor } \\
\text { or substrate) }\end{array}$ & Adverse effects & $\begin{array}{l}\text { Administration } \\
\text { method and } \\
\text { dosage }\end{array}$ & References \\
\hline $\begin{array}{l}\text { Lopinavir/ } \\
\text { Ritonavir }\end{array}$ & $\begin{array}{l}\text { SARS- } \\
\text { CoV-2 }\end{array}$ & $\begin{array}{l}\text { Protease } \\
\text { inhibitor, inhibits } \\
\text { 3CLpro }\end{array}$ & No effect & $\begin{array}{l}\text { An inhibitor for } \\
\text { CYP3A4 }\end{array}$ & $\begin{array}{l}\text { Hypertension, prolonged } \\
\text { P-R and prolonged QT } \\
\text { interval, torsade de } \\
\text { pointes, severe } \\
\text { conduction disorders, } \\
\text { and cardiac arrhythmias }\end{array}$ & $\begin{array}{l}\text { Oral. Twice a day and } \\
\text { two capsules each time } \\
\text { with } 200 \mathrm{mg} / 50 \mathrm{mg} / \\
\text { capsule for adults. It is } \\
\text { worth note that the } \\
\text { course of treatment is } \\
\text { not more than } 10 \text { days }\end{array}$ & $\begin{array}{l}\text { Cao et al. (2020), } \\
\text { Gerard et al. (2020), } \\
\text { Li and De Clercq, } \\
\text { (2020), Pillaiyar et al. } \\
\text { (2020), Zhang et al. } \\
\text { (2020g) }\end{array}$ \\
\hline Remdesivir & $\begin{array}{l}\text { SARS- } \\
\text { CoV-2 }\end{array}$ & $\begin{array}{l}\text { Protease } \\
\text { inhibitor, inhibits } \\
\text { SARS-CoV- } \\
2 \text { RNA- } \\
\text { dependent RNA } \\
\text { polymerase }\end{array}$ & Positive & $\begin{array}{l}\text { An inhibitor for viral } \\
\text { RNA polymerase }\end{array}$ & $\begin{array}{l}\text { Hypotension, } \\
\text { bradycardia, QTc } \\
\text { prolongation, T-wave } \\
\text { abnormality }\end{array}$ & $\begin{array}{l}\text { Intravenous infusion. } \\
200 \text { mg on the first day, } \\
\text { and followed by } \\
100 \text { mg on day } 2-10 \text { or } \\
\text { until discharge }\end{array}$ & $\begin{array}{l}\text { Beigel et al. (2020), } \\
\text { Fan et al. (2020), } \\
\text { Gubitosa et al. } \\
\text { (2020), Gupta et al. } \\
\text { (2020), Horby et al. } \\
\text { (2020), Spinner et al. } \\
\text { (2020), Touafchia } \\
\text { et al. (2021), Wang } \\
\text { et al. (2020g) }\end{array}$ \\
\hline Interferon a & $\begin{array}{l}\text { SARS- } \\
\text { CoV-2 }\end{array}$ & $\begin{array}{l}\text { Protease } \\
\text { inhibitor, viral } \\
\text { load reduction } \\
\text { through inhibition } \\
\text { of replication }\end{array}$ & Positive & $\begin{array}{l}\text { An inhibitor for } \\
\text { CYP3A4 }\end{array}$ & $\begin{array}{l}\text { Ischemic } \\
\text { cardiomyopathy, } \\
\text { arrhythmias, and } \\
\text { hypertension or } \\
\text { hypotension }\end{array}$ & $\begin{array}{l}\text { Aerosol inhalation. } 5 \\
\text { million units or } \\
\text { equivalent mixed with } \\
2 \text { ml of sterile water } \\
\text { twice per day for adults }\end{array}$ & $\begin{array}{l}\text { Hariramnile et al. } \\
\text { (2020), Mantlo et al. } \\
\text { (2020), Sallard et al. } \\
\text { (2020), Wang and } \\
\text { Fish (2020a) }\end{array}$ \\
\hline Ribavirin & $\begin{array}{l}\text { SARS- } \\
\text { CoV-2 }\end{array}$ & $\begin{array}{l}\text { Viral load } \\
\text { reduction } \\
\text { through inhibition } \\
\text { of replication }\end{array}$ & Negative & $\begin{array}{l}\text { A substrate for viral } \\
\text { RNA capping enzyme }\end{array}$ & $\begin{array}{l}\text { Bradycardia, cardiac } \\
\text { dysfunction, anemia, } \\
\text { hypomagnesemia, } \\
\text { dyspnea and chest pain; } \\
\text { mitochondrial toxicity } \\
\text { and energy metabolism } \\
\text { disorder of } \\
\text { cardiomyocytes }\end{array}$ & $\begin{array}{l}\text { Intravenous infusion. } \\
500 \text { mg/time, twice or } \\
\text { triple per day with a } \\
\text { combination of } \\
\text { interferon or lopinavir/ } \\
\text { ritonavir, and the } \\
\text { course of therapy is not } \\
\text { more than } 10 \text { days }\end{array}$ & $\begin{array}{l}\text { Elfiky, (2020a), Elfiky, } \\
\text { (2020b), Hung et al. } \\
\text { (2020), Li and De } \\
\text { Clercq, (2020), Ma } \\
\text { et al. (2020), Wang } \\
\text { et al. (2020c) }\end{array}$ \\
\hline Chloroquine & $\begin{array}{l}\text { SARS- } \\
\text { CoV-2 }\end{array}$ & $\begin{array}{l}\text { Viral load } \\
\text { reduction } \\
\text { through inhibition } \\
\text { of replication }\end{array}$ & Negative & $\begin{array}{l}\text { An inhibitor for } \\
\text { phosphatidylinositol-3- } \\
\text { kinase (PI3K)/Akt } \\
\text { pathway }\end{array}$ & $\begin{array}{l}\text { Hypotension, } \\
\text { hypokalemia, QRS and } \\
\text { QT prolongation, } \\
\text { atrioventricular block, } \\
\text { arrhythmias and even } \\
\text { coma }\end{array}$ & $\begin{array}{l}\text { Oral. (1). } 500 \text { mg/time, } \\
\text { twice per day, } 7 \text {-days } \\
\text { course for weight of } \\
\text { patients over } 50 \mathrm{~kg} \text {; (2). } \\
500 \mathrm{mg} / \text { time, twice per } \\
\text { day in the first } 2 \text { days, } \\
\text { and } 500 \mathrm{mg} / \text { time, once } \\
\text { per day in the next } \\
5 \text { days for weight of } \\
\text { patients less than } 50 \\
\text { kg. It is forbidden in } \\
\text { patients with heart } \\
\text { disease }\end{array}$ & $\begin{array}{l}\text { Aggarwal et al. } \\
\text { (2020), Beigel et al. } \\
\text { (2020), Brown et al. } \\
\text { (2020), Cavalcanti } \\
\text { et al. (2020), Cui et al. } \\
\text { (2020), Ferner and } \\
\text { Aronson, (2020), } \\
\text { Geleris et al. (2020), } \\
\text { Jankelson et al. } \\
\text { (2020), Ledford, } \\
\text { (2020), Liu et al. } \\
\text { (2020b), Mercuro } \\
\text { et al. (2020), Rome } \\
\text { and Avorn, (2020), } \\
\text { Rosenberg et al. } \\
\text { (2020), Shah et al. } \\
\text { (2020), Wang et al. } \\
\text { (2020c), Wong, } \\
\text { (2020), Wu et al. } \\
\text { (2020), Zhang et al. } \\
\text { (2020g) }\end{array}$ \\
\hline Baricitinib & $\begin{array}{l}\text { SARS- } \\
\text { CoV-2 }\end{array}$ & $\begin{array}{l}\text { Protease } \\
\text { inhibitor, inhibits } \\
\text { Janus kinase } 1 / 2\end{array}$ & Positive & $\begin{array}{l}\text { An inhibitor of Janus } \\
\text { kinases (JAK) }\end{array}$ & $\begin{array}{l}\text { Hyperglycaemia, } \\
\text { infections and } \\
\text { thromboembolic events }\end{array}$ & $\begin{array}{l}\text { Oral or a nasogastric } \\
\text { tube. } 4 \text { mg (two 2-mg } \\
\text { tablets) once daily for } \\
\text { up to } 14 \text { days or until } \\
\text { hospital discharge. It is } \\
\text { recommended in } \\
\text { combination with }\end{array}$ & $\begin{array}{l}\text { Cantini et al., 2020, } \\
\text { Favalli et al. (2020), } \\
\text { Kalil et al. (2021), } \\
\text { Magro, (2020), } \\
\text { Richardson et al. } \\
\text { (2020), Stebbing }\end{array}$ \\
\hline
\end{tabular}

(Continued on following page) 
TABLE 1 | (Continued) Antiviral and anti-inflammatory drugs that have been suggested for the treatment of COVID-19 infection.

\begin{tabular}{|c|c|c|c|c|c|c|}
\hline $\begin{array}{l}\text { Antiviral and } \\
\text { anti- } \\
\text { inflammatory } \\
\text { drugs }\end{array}$ & $\begin{array}{c}\text { Targeted } \\
\text { virions }\end{array}$ & Mechanism & $\begin{array}{c}\text { Total } \\
\text { direction } \\
\text { of effect }\end{array}$ & $\begin{array}{c}\text { Pharmacokinetic } \\
\text { role (inhibitor } \\
\text { or substrate) }\end{array}$ & Adverse effects & $\begin{array}{c}\text { Administration } \\
\text { method and } \\
\text { dosage }\end{array}$ \\
\hline
\end{tabular}

remdesivir in patients with COVID-19 who require oxygen or ventilatory support

\begin{tabular}{|c|c|c|c|c|}
\hline Arbidol & $\begin{array}{l}\text { SARS- } \\
\text { CoV-2 }\end{array}$ & $\begin{array}{l}\text { Protease } \\
\text { inhibitor, inhibits } \\
\text { glycoprotein }\end{array}$ & Positive & $\begin{array}{l}\text { An inhibitor of } S \\
\text { CoV-2 }\end{array}$ \\
\hline Dexamethasone & $\begin{array}{l}\text { SARS- } \\
\text { CoV-2 }\end{array}$ & $\begin{array}{l}\text { Combat cytokine } \\
\text { storm by limiting } \\
\text { the production of } \\
\text { and damaging } \\
\text { effect of the } \\
\text { cytokines }\end{array}$ & Positive & $\begin{array}{l}\text { A substrate for } \\
\text { CYP3A4 }\end{array}$ \\
\hline
\end{tabular}

Tocilizumab SARSCoV-2

Inhibit the activity Positive of IL-6 receptor, block the "cytokine storm" caused by IL-6 pathway

Anakinra

SARSCoV-2
An inhibitor for Interleukin-6 (IL-6) receptor

An inhibitor of SARSCoV-2

An inhibitor for Interleukin-1 (IL-1) receptor
Oral. 200 mg/time and
Protease Positive inhibitor, inhibits IL-1 receptor, block the "cytokine storm" caused by IL-1 pathway

et al. (2020), Zhang et al. (2020f) triple per day, and the course of therapy is not more than 10 days vomiting, and bradycardia

Arrhythmias, headache, agitation, dizziness, and increased appetite
Oral or intravenous infusion. $6 \mathrm{mg}$ once daily for up to 10 days or until hospital discharge cardiomyopathy, liver injury, and infection such as an increase in serum cholesterol, ALT, AST, and injection site reaction
Intravenous infusion. $400 \mathrm{mg}$ dissolving $100 \mathrm{ml} \mathrm{0.9 \%}$ sodium chloride; infusion time should be more than $1 \mathrm{~h}$; the cumulative number of times of administration is 2 at most; caution with allergic reaction; forbidden for those with tuberculosis infection

Subcutaneous a day for $72 \mathrm{~h}$, then $100 \mathrm{mg}$ daily for 7 days injection.100 mg twice

Deng et al. (2020), L et al. (2020), Vankadari, (2020), Wang et al. (2020e), Xu et al. (2020), Zhu et al. (2020) Ahmed and Hassan, (2020), Garibaldi et al. (2020), Horby et al. (2020), Jo et al. (2021), Johnson and Vinetz, (2020), Lester et al. (2020), Lim and Pranata, (2020),

Matthay and Thompson, (2020), Patel et al. (2020), Prescott and Rice, (2020), Sharun et al. (2020), Sterne et al. (2020), Vetter et al. (2020)

Alattar et al. (2020), Brown et al. (2020), Fu et al. (2020), Hermine et al. (2021), Khiali et al. (2020), Luo et al. (2020), Morena et al. (2020), Muhovic et al. (2020), Xu et al. (2020)

Hypersensitivities, hyperinfammation, breathing problem, nausea, vomiting diarrhea, headache, joint pain (2020), Dos Santos
Aouba et al. (2020), Bilia et al. (2020), Bozzi et al. (2021), Cauchois et al. (2020), Cavalli et al. (2020), Haigh et al. (2020), Hossen et al. (2020), Huet et al. (2020), Jamilloux et al. (2020), Kooistra et al. (2020), Langer-Gould et al. (2020), Manjaly Thomas et al. (2020), Navarro-Millán et al. (2020), Pasin et al. (2021), Salvi and Patankar, (2020), Wu et al. (2020) 


\section{TREATMENT PLAN FOR CARDIOVASCULAR COMPLICATIONS OF COVID-19}

Common treatment of COVID-19 patients with cardiovascular complications includes traditional care, coronary angiography and percutaneous coronary intervention if indicated, the use of anticoagulants and antiplatelet agents, and supportive care. Some patients with circulatory collapse may need extracorporeal circulatory support. Next, we briefly summarize the cardiovascular complications of anti-COVID-19 drug therapy (Table 1).

\section{Antiviral Treatments Lopinavir/Ritonavir}

Lopinavir is a human immunodeficiency virus (HIV) protease inhibitor, which was approved by the US Food and Drug Administration (FDA) in 2000 and allowed for listing in China in 2008 (Oldfield and Plosker, 2006). Lopinavir inhibits the action of the enzyme 3-chymotrypsin-like protease and P-glycoprotein, which plays a crucial role in the distribution and elimination of lopinavir (Zhang et al., 2020c). Ritonavir is used in combination with lopinavir because it can increase the half-life of lopinavir by inhibiting the metabolizing enzyme cytochrome P450 3A (Abbvie, 2020). The combination of lopinavir and ritonavir has been preferred for the treatment of COVID-19 (Cao et al., 2020; Li and De Clercq, 2020; Pillaiyar et al., 2020). However, it has recently been shown to be ineffective according to a randomized controlled trial (Cao et al., 2020). Interestingly, common adverse reactions of the combination of lopinavir and ritonavir include hypertension, prolonged P-R and prolonged QT interval, torsade de pointes, severe conduction disorders, and cardiac arrhythmias (Badiou et al., 2003; Abbvie, 2012; Gerard et al., 2020). Additionally, the combination of lopinavir/ritonavir can induce drug-related cardiotoxicity by regulating cardiomyocyte pyroptosis, lysosome-mediated protein degradation, calcium signaling pathway, and the phosphatidylinositol 3-kinase (PI3K)/protein serine threonine kinase (Akt) signaling pathway (Reyskens et al., 2013). Therefore, changes in electrocardiograms and alteration of blood lipids should be monitored and checked in patients with COVID-19 and dyslipidemia. The current mode of administration of lopinavir/ritonavir is oral, and the recommended dose is twice a day and two capsules each time with $200 \mathrm{mg} / 50 \mathrm{mg} /$ capsule for adults. The course of treatment lasts less than 10 days.

\section{Remdesivir}

Remdesivir is an inhibitor of viral RNA-dependent RNA polymerase (RdRp) with broad-spectrum activity against several members of the virus family such as coronaviruses (e.g., SARS-CoV and MERS-CoV) and filoviruses (e.g., Ebola). $\mathrm{RdRp}$ is essential for the replication of SARS-CoV-2 (Spinner et al., 2020). Remdesivir is currently the only drug approved by the FDA for the treatment of COVID-19. It is usually used in hospitalization of patients who require supplemental oxygen. Until now, remdesivir and dexamethasone have been recommended as first-line antiviral therapy for COVID-19 (Fan et al., 2020; Horby et al., 2020; Spinner et al., 2020). Remdesivir shows an excellent antiviral infection ability in vivo experiment $(\mathrm{EC} 50=0.77 \mu \mathrm{M} ; \mathrm{CC} 50>100 \mu \mathrm{M}$; SI > 129.87) compared to favipiravir, ribavirin, penciclovir, nitazoxanide, nafamostat, and chloroquine (Wang et al., 2020c). Although remdesivir has a numerically faster time to clinical improvement than placebo in patients, there was no statistically significant difference between the two groups. Notably, remdesivir is not recommended for mild patients due to a high incidence of adverse events (Wang et al., 2020g). Another larger study confirms that remdesivir was superior to placebo in shortening recovery time and reducing the incidence of adverse events (Beigel et al., 2020). Known adverse events of remdesivir are hypotension, bradycardia, QTc prolongation, and T-wave abnormality (Gubitosa et al., 2020; Gupta et al., 2020; Touafchia et al., 2021).

\section{Interferon- $\alpha$ (IFN- $\alpha$ )}

IFN- $\alpha$, a low molecular glycoprotein, is characterized by antiviral, antiproliferative, antidifferentiation, and immunoregulatory functions. IFN- $\alpha$ is used for the control of COVID-19 in light of the urgency to confront the COVID-19 pandemic (Hariramnile et al., 2020; Sallard et al., 2020; Wang and Fish, 2020a). Type I interferon inhibited SARS-CoV-2 in vitro experiments (Mantlo et al., 2020). The main adverse reactions of IFN- $\alpha$ include ischemic cardiomyopathy, arrhythmias, and hypertension or hypotension (Sleijfer et al., 2005; Pichler, 2006; Kuo et al., 2018). In addition, it causes endothelial dysfunction by promoting the expression of factors related to oxidative stress (Buie et al., 2017). IFN- $a$ can also cause acute myocardial injury by enhancing atherosclerotic plaques polarization of in M1 macrophages and inhibit angiogenesis by regulating signal transduction and activator of transcription 1 (STAT1) and STAT3 (Nelson et al., 2015; Hsu et al., 2017). The mode of administration of IFN- $\alpha$ is aerosol inhalation, and the recommended dose is 5 million units or equivalent mixed with $2 \mathrm{ml}$ of sterile water twice per day for adults. Although the drug is administered locally in the respiratory tract, one should be vigilant of its cardiotoxicity and pay close attention to electrocardiogram changes, the development of acute myocardial infarction, and heart failure, especially in elderly patients with preexisting cardiovascular diseases.

\section{Ribavirin}

Ribavirin is a purine nucleoside analogue with broad-spectrum antiviral activity, which can effectively inhibit the proliferation of a variety of respiratory viruses. Ribavirin overdoses can increase the risks of bradycardia (17\%), anemia (27\%), and hypomagnesemia (45\%) (Muller et al., 2007). It is administered in different ways in various diseases (Ma et al., 2020). This drug can also be used in both pediatric and adult populations co-infected with hepatitis B and HIV. At present, ribavirin combined with interferon and/or lopinavir/ritonavir is recommended for patients with COVID-19 (Elfiky, 2020a; Elfiky, 2020b; Hung et al., 2020; Li and De Clercq, 2020). Wang et al. reported that ribavirin can inhibit virus growth $\left(\mathrm{EC}_{50}=\right.$ 
$109.50 \mu \mathrm{M}, \mathrm{CC}_{50}>400 \mu \mathrm{M}, \mathrm{SI}>3.65$ ) in Vero E6 cells (Wang et al., 2020c). Common adverse reactions of ribavirin include dyspnea and chest pain, especially in patients with COPD and asthma (Lu et al., 2015). Long-term (lasting 13 days) and highdose (600 mg twice per day) ribavirin increased the risk of developing cardiovascular disease events and raised the risk of death in patients with cardiovascular disease (Beigel et al., 2017). Ribavirin can induce mitochondrial toxicity and energy metabolism disorders of cardiomyocytes by promoting mitochondrial calcium metabolism disorders (Lafeuillade et al., 2001). Therefore, ribavirin may increase the risk of cardiac dysfunction in patients with preexisting cardiovascular diseases. The recommended administration of ribavirin for COVID-19 is intravenous infusion (500 mg, 2-3 times a day) with interferon- $\alpha$ or lopinavir/ritonavir, and the duration of therapy is not longer than 10 days.

\section{Chloroquine}

Chloroquine is used mainly in the treatment of malarial and rheumatic diseases (Savarino et al., 2003; Wang et al., 2020c; Wu et al., 2020). It served to treat COVID-19 patients due to the characteristic of inhibiting endosomal acidification required for virus-host cell fusion. Chloroquine has been the drug of choice for large-scale use in the treatment of COVID-19 patients due to its wide availability, proven safety record, and relatively low cost (Cui et al., 2020; Ledford, 2020; Shah et al., 2020). However, excessive use of chloroquine can cause cardiovascular dysfunction such as hypotension, hypokalemia, QRS and QT prolongation, atrioventricular block, arrhythmias, and even coma (Wong, 2020). In addition, COVID-19 patients receiving a combination of hydroxychloroquine and azithromycin had a longer QT interval than those taking hydroxychloroquine alone in a cohort study (Mercuro et al., 2020). Furthermore, recent studies demonstrated that chloroquine and hydroxychloroquine were not effective drugs for COVID-19 (Brown et al., 2020; Cavalcanti et al., 2020; Ferner and Aronson, 2020; Rosenberg et al., 2020). The therapeutic dose of drugs is in a narrow concentration range that requires appropriate doses for different populations.

Common derivatives of chloroquine (CQ) are chloroquine phosphate (PCQ) and hydroxychloroquine (HCQ). PCQ, as an approved immune modulator, can effectively block SARS-CoV-2/ $2019-\mathrm{nCoV}$ infection $\left(\mathrm{EC}_{50}=1.13 \mu \mathrm{M} ; \mathrm{CC}_{50}>100 \mu \mathrm{M}\right.$, SI > 88.50) in Vero E6 cells (Beigel et al., 2020). PCQ can control the electrophysiological activity of the heart by regulating the energy metabolism of cardiac myocytes, voltagegated ion channels, calcium channel, and electrochemistry transporters (Mubagwa, 2020). However, CQ can induce serious cardiovascular reactions such as arrhythmias, shock, and Adams-Stokes syndrome (Pareek et al., 2018). Recently, several reviews have noted out that CQ and HCQ induce significant prolongation of the QT interval and potentially increase the risk of serious arrhythmias and sudden death (Aggarwal et al., 2020; Jankelson et al., 2020; Zhang et al., 2020g).

The structures and mechanisms of HCQ and CQ are similar to those of PCQ. Wang et al. showed that HCQ can effectively block the replication of SARS-CoV-2 in vitro and improve the clinical symptoms of patients with COVID-19 (Wang et al., 2020c). Previous studies have shown that HCQ can reduce cardiovascular risk, especially the incidence of cardiac dysfunction in patients with myocardial infarction (Liu et al., 2018; Rempenault et al., 2018; Schrezenmeier and Dörner, 2020). Although the FDA has authorized the use of HCQ and CQ for the treatment of COVID-19, one still needs to be aware of its adverse cardiovascular reactions such as atrioventricular block, cardiomyopathy, and heart failure. Compared with CQ, HCQ is less toxic and more potent in inhibiting SARS-CoV-2 infection in vitro (Liu et al., 2020b). There is no association between HCQ administration and the risk of composite endpoint of intubation or death based on an observational study (Geleris et al., 2020). There is no proven benefit for the use of HCQ in patients with COVID-19. In addition, it is worth noting that CQ has been revoked with the emergency use authorization (EUA) by the FDA (Rome and Avorn, 2020).

\section{Baricitinib}

Baricitinib is known as an inhibitor of Janus-associated kinase (JAK), specifically referring to JAK1 and JAK2, which is approved by the FDA and the EU for the treatment of rheumatoid arthritis with high efficacy and safety records (Markham, 2017). It was identified as the numb-associated kinase inhibitor (NAK) with selectivity of the adapter protein-2 complex (AP2)-associated protein kinase 1 (AAK1) and cyclin G-associated kinase (GAK) that are mediators or regulators of viral endocytosis (Stebbing et al., 2020). Inhibition of AAK1 by baricitinib can interrupt virus entry into cells and subsequently stop intracellular assembly and virus replication. In summary, baricitinib against COVID-19 relies mainly on inhibiting cytokine release and SARS-CoV-2 endocytosis (Magro, 2020; Richardson et al., 2020; Zhang et al., 2020f). A recent study found that baricitinib improved clinical conditions in 12 patients with mild and moderate COVID-19 (Cantini et al., 2020a). Another study demonstrated that baricitinib had a lower fatality rate and admission to the ICU, but a higher discharge rate compared with controls at week 1 and week 2 (Cantini et al., 2020b). However, baricitinib was not recommended to treat patients with severe COVID-19 with susceptible constitution, at least be cautious (Favalli et al., 2020). Up to now, baricitinib and remdesivir have been vapproved by the FDA through emergency use authorization (EUA) for hospitalized COVID-19 patients (Kalil et al., 2021). Nonetheless, baricitinib is not an approved standalone drug by the FDA for COVID-19 treatment. The common adverse effect of baricitinib on COVID-19 is hyperglycemia, infections, and thromboembolic events.

\section{Arbidol}

Arbidol is a non-nucleoside antiviral drug mainly for the treatment of influenza and other viral infections, which has inhibitory effects on both enveloped and nonenveloped viruses (Boriskin et al., 2008; Liu et al., 2009; Blaising et al., 2014). As a highly selective hemagglutinin inhibitor, arbidol can effectively target the hemagglutinin fusion machinery and prevent CoVs from anchoring the cell surface and invading cells (Blaising et al., 2014). Arbidol can block the trimerization of the SARS-CoV-2 
spike glycoprotein and host cell adhesion, and effectively inhibit SARS-CoV-2 in vitro (Deng et al., 2020; Vankadari, 2020; Wang et al., 2020e). A recent study suggested that arbidol was superior to lopinavir/ritonavir against COVID-19 (Zhu et al., 2020). The combination of arbidol and lopinavir/ritonavir was better than lopinavir/ritonavir in anti-COVID-19 therapy (Deng et al., 2020). In addition, arbidol alone could be used to treat COVID-19 patients with mild symptoms (Xu et al., 2020). However, a recent study showed that neither arbidol nor lopinavir/ritonavir could beneficially affect the outcomes of COVID-19 patients, and contributed to adverse effects such as diarrhea, poor appetite, and abnormal liver function (Li et al., 2020b). Common cardiovascular adverse effects of arbidol include nausea, diarrhea, dizziness, liver injury, vomiting, and bradycardia. The recommended dose of arbidol for COVID-19 patients is $200 \mathrm{mg}$ PO each time and three times per day, and the course of therapy is not longer than 10 days.

\section{Other Antiviral Drugs}

Other common candidate antiviral drugs for COVID-19 are fapiravir, penciclovir, sofosbuvir, and galidesivir (Pillaiyar et al., 2020; Richardson et al., 2020; Wang et al., 2020c). Their main adverse effects include hypotension and arrhythmias. Fapiravir is a broad-spectrum anti-influenza drug, which exerts an antiviral effect mainly by inhibiting RNA synthetase (Gao et al., 2020; Wang et al., 2020c). Sofosbuvir is an FDA-approved drug that is mainly used to treat patients with hepatitis $\mathrm{C}$ with various genotypes. Sofosbuvir is converted in a host cell to its active form, nucleoside triphosphate through phosphorylation, which terminates RNA replication in the nascent viral genome through competition with the nucleotides of invasive viruses (Sayad et al., 2020). Elfiky reported that sofosbuvir, ribavirin, remdesivir, galidesivir and tenofovir can be bound to COVID19 RNA polymerase and are potent drugs against COVID-19 infection (Elfiky, 2020b). In vitro experiments indicate that remdesivir $\left(\mathrm{EC}_{50}=0.77 \mu \mathrm{M} ; \mathrm{CC}_{50}>100 \mu \mathrm{M}\right.$; SI > 129.87), fapiravir $\left(\mathrm{EC}_{50}=61.88 \mu \mathrm{M}, \mathrm{CC}_{50}>400 \mu \mathrm{M}\right.$, SI $\left.>6.46\right)$ and penciclovir $\left(\mathrm{EC}_{50}=95.96 \mu \mathrm{M}, \mathrm{CC}_{50}>400 \mu \mathrm{M}\right.$, SI > 4.17) can effectively inhibit SARS-CoV-2 (Wang et al., 2020c). However, these drugs have their own cardiovascular risk. For example, Mulangu et al. (2019) reported that an Ebola patient who received remdesivir had hypotension and subsequently died due to cardiac arrest. Caldeira et al. (2018) suggested an increased risk of serious bradycardia among patients treated with sofosbuvir and amiodarone based on an observational study. Taken together, cardiovascular complications and risks of antiviral drugs need to be taken into account when used in COVID-19 patients.

\section{Anti-Inflammatory and Immunotherapy Drugs}

Anti-inflammatory and immunotherapy drugs can alter the workings of the immune system, so it can find, attack, and eliminate invasive pathogens and finally get rid of them. Thus, it is an efficient therapeutic option against viral infections, including patients with COVID-19 characterized by the cytokine storm (Aminjafari and Ghasemi, 2020; Blanco-Melo et al., 2020; Vabret et al., 2020).

\section{Dexamethasone}

Dexamethasone, as a representative anti-inflammatory drug, is a broad-spectrum immunosuppressor approved by the FDA with high activity and a long duration of action. It will inhibit the release and subsequent detrimental effect of cytokines to further combat symptoms of hyperinflammation or cytokine storm in COVID-19 (Lim and Pranata, 2020; Sharun et al., 2020). Recently, preliminary clinical trials of dexamethasone have been approved by the WHO based on the significant improvement in reducing mortality by $35 \%$ in ventilated patients and $20 \%$ in other patients receiving oxygen (Horby et al., 2020; Patel et al., 2020; WHO, 2020). However, there is a lack of clinical benefit of dexamethasone in non-critical patients without respiratory support such as ventilation or oxygen (Johnson and Vinetz, 2020; Lester et al., 2020). Dexamethasone can increase mortality in patients without critical illness who did not receive respiratory support (Matthay and Thompson, 2020). It is notable that a low dose of dexamethasone could only reduce the mortality of patients with severe COVID-19, but had no effect on the mortality of patients with mild and moderate COVID-19 patients; while high doses of dexamethasone contributed to more harm than good (Ahmed and Hassan, 2020; Prescott and Rice, 2020; Sterne et al., 2020). Additionally, the combination of dexamethasone and remdesivir may reduce mortality, which has been recommended to treat COVID-19 patients with mild-moderate conditions (Garibaldi et al., 2020; Vetter et al., 2020; Jo et al., 2021). It is worth noting that dexamethasone treatment can lead to several adverse effects such as arrhythmias, headache, agitation, dizziness, and increased appetite.

\section{Tocilizumab}

Tocilizumab, a humanized recombinant monoclonal antibody against interleukin-6 (IL-6), can inhibit the activity of the IL-6 receptor by binding to its membrane-bound and soluble forms, and thus block the "cytokine storm" caused by IL-6 (Xie et al., 2019). Recently, tocilizumab was used to treat COVID-19 patients at risk of cytokine storm (Brown et al., 2020). However, the adverse effects of tocilizumab should not be ignored, such as cardiomyopathy and liver injury (Muhovic et al., 2020). Gabay et al. (2016) found that tocilizumab induced cardiomyocyte apoptosis and mitochondrial oxidative stress resulting in cardiotoxicity, manifested as hypertension, hypercholesterolemia and myocardial infarction, which remind clinicians to pay attention to the above-mentioned adverse effects of tocilizumab when combating COVID-19. The most common adverse reactions and events were infections that were characterized by an increase in serum cholesterol, ALT, AST, and injection site reactions (Khiali et al., 2020). Luo et al. (2020) found that tocilizumab alleviated inflammatory activity in COVID-19 patients. Xu et al. (2020) demonstrated that abnormally elevated C-reactive protein and the number of lymphocytes decreased in 84 and $37 \%$ of patients, respectively. 
The average discharge time of patients treated with tocilizumab was 15.1 days, and this therapy effectively improved mortality in patients with severe and critically ill COVID-19 (Xu et al., 2020). It is worth of mentioning that an increasing trend of IL-6 occurs immediately when tocilizumab usage is reduced. Alattar et al. (2020) showed that tocilizumab caused adverse events such as anemia, QT interval prolongation, and ananine aminotransferase increase. Morena et al. (2020) demonstrated that COVID-19 patients treated with tocilizumab experienced adverse events included thrombocytopenia, increase of hepatic enzymes, and serious bacterial and fungal infections. Hermine et al. (2021) reported that tocilizumab induced cardiovascular adverse events manifested by hypertension, anemia, lymphopenia, and neutropenia, and bacterial sepsis. Fu et al. (2020) pointed out that tocilizumab treatment inhibited the inflammatory storm, resulting in an improved clinical outcome. Castagné et al. (2019) found that tocilizumab was associated with an elevated cholesterol level, which decreased inflammatory proteins and restored the antiatherogenic function of $\mathrm{HDL}$ cholesterol. It should be used with caution in patients with dyslipidemia and hypertension. The recommended dose of tocilizumab for COVID-19 patients is $400 \mathrm{mg}$ dissolved in $100 \mathrm{ml}$ of $0.9 \%$ sodium chloride; infused in $>1 \mathrm{~h} 2$ times at most; while looking for an allergic reaction.

\section{Anakinra}

Anakinra is one of the anti-interleukin 1 antagonist which can inhibit actions of IL-1 receptor to suppress the pathogeny of proinflammatory cytokine storm in COVID-19 (Aouba et al., 2020; Dos Santos, 2020; Jamilloux et al., 2020; Salvi and Patankar, 2020; Wu et al., 2020). Therefore, it has been used for the treatment of COVID-19 patients. Several studies indicated that anakinra is a safe and effective drug combating COVID-19 patients with cytokine storm signs (Bilia et al., 2020; Cauchois et al., 2020; Haigh et al., 2020; Huet et al., 2020; Navarro-Millán et al., 2020; Bozzi et al., 2021; Pasin et al., 2021). Cavalli et al. (2020) found that high-dose anakinra was associated with clinical improvement in $72 \%$ of patients with COVID-19 and acute respiratory distress syndrome in a retrospective cohort study. Langer-Gould et al. (2020) demonstrated that early identification and treatment of COVID-19 cytokine storm with anakinra significantly improved outcomes after mechanical ventilation. Kooistra et al. (2020) showed that anakinra can reduce clinical symptoms of hyperinflammation in critically ill COVID-19 patients. The main adverse effects of anakinra were hypersensitivities, hyperinfammation, breathing problem, nausea, vomiting diarrhea, headache, and joint pain (Hossen et al., 2020; Kooistra et al., 2020; Manjaly Thomas et al., 2020).

\section{Convalescent Plasma for COVID-19 Treatment}

Convalescent plasma refers to plasma collected from COVID-19 convalescent patients, which can contribute to a safe and effective therapy for COVID-19 patients. Previous studies in a variety of viral respiratory diseases, such as SARS and MERS, indicated that convalescent plasma can reduce mortality. Therefore, convalescent plasma may provide a potential therapy for COVID-19 patients (Bloch et al., 2020; Chen et al., 2020; Tiberghien et al., 2020). Notably, the efficacy of convalescent plasma against COVID-19 remains to be proved (Casadevall and Pirofski, 2020; Roback and Guarner, 2020).

Several observed studies found that plasma convalescent therapy is effective and specific for COVID-19 (Duan et al., 2020; Shen et al., 2020; Ye et al., 2020). However, there is one point of view that convalescent plasma is ineffective for COVID19 (Pathak, 2020; Rogers et al., 2020). In a word, the efficacy of convalescent plasma therapy for COVID-19 is controversial. Adequately powered and randomized controlled trials are needed to confirm the efficacy of convalescent plasma therapy for COVID-19 (Bloch, 2020; Liu et al., 2020e). Recently, several randomized controlled trials demonstrated that the efficiency in different cases using plasma convalescent therapy is inconsistent (Agarwal et al., 2020; Li et al., 2020c; Klassen et al., 2020; Simonovich et al., 2021). However, convalescent plasma was found to be relatively safe, in more than 20,000 patients with a low incidence of severe adverse events $(<1 \%)$ (Joyner et al., 2020). The general known cardiovascular risks of plasma transfusion generally include transfusion-associated circulatory overload, hypercoagulablility, and thrombosis (Sanfilippo et al., 2021).

\section{Traditional Chinese Medicine for COVID-19 Treatment}

Traditional Chinese Medicine (TCM) is usually defined by a mixture of herbal plants or their extracts which comprise hundreds of constituents with various differing physiochemical properties (Zhou, 2020). TCM is a unique health resource in China, which is also a vast and large untapped resource in the world. For example, artemisinin, a safe and effective antimalarial drug, was originally extracted from Artemisia annua by TCM scientific workers (Tu, 2016). In addition, in view of the remarkable therapeutic effects that TCM achieved during the SARS epidemic in 2003, TCM raises hopes for the prevention and control of COVID-19 (Luo et al., 2020). Several TCMs have been recommended by the China National Health Commission to treat COVID-19 patients because the advantages far outweigh the disadvantages, which are characterized mainly by promoting neutrophil-mediated inflammation and reducing macrophagemediated anti-inflammatory activity (Wang et al., 2020f; Tong et al., 2020; Zhang, 2020b). Over 90\% of COVID-19 patients in China have been treated with TCM, and some studies showed relief of symptom, reducing the time of onset of fever and reducing the severity of the disease (Du et al., 2020; Liu et al., 2020c; Ren et al., 2020). Common TCMs combating COVID-19 are HuoxiangZhengqi capsules, LianhuaQingwen capsules, Jinhuaqinggan granula, ShufengJiedu capsules, Fangfengtongsheng pill, Qingfeipaidu decoction, Suhexiang pill, Angongniuhuang pill, and XueBijing injection (Li et al., 2020d; Ren et al., 2020; Tong et al., 2020; Wang et al., 2020f). Different of the above-mentioned TCMs are used to treat different diseases and different courses of the same disease (Table 2). The key mechanism of TCM is inflammation regulation (Li et al., 2020). In addition, 
TABLE 2 | Nine TCMs recommended by guidelines of treatment for COVID-19.

\begin{tabular}{|c|c|c|c|}
\hline TCMs & Stage of diseases & Symptoms & References \\
\hline $\begin{array}{l}\text { HuoxiangZhengqi capsules (HXZQ) - 藿香 } \\
\text { 正气胶囊 }\end{array}$ & $\begin{array}{l}\text { Medical observation } \\
\text { period }\end{array}$ & Fatigue with gastro-intestinal discomfort & Luo et al. (2020), Tong et al. (2020), Wang et al. (2020f) \\
\hline $\begin{array}{l}\text { LianhuaQingwen capsules (LHQW) - 连花 } \\
\text { 清瘟胶囊 }\end{array}$ & $\begin{array}{l}\text { Medical observation } \\
\text { period }\end{array}$ & Fatigue with fever & $\begin{array}{l}\text { Li et al. (2020), Luo et al. (2020) } \\
\text { Tong et al. (2020), Wang et al. (2020f) }\end{array}$ \\
\hline $\begin{array}{l}\text { JinhuaQinggan granula (JHQG) - 金花清 } \\
\text { 感颗粒 }\end{array}$ & $\begin{array}{l}\text { Medical observation } \\
\text { period }\end{array}$ & Fatigue with fever & Wang et al. (2020f) \\
\hline $\begin{array}{l}\text { ShufengJiedu capsules (SFJD) - 疏风解毒 } \\
\text { 胶蓑 }\end{array}$ & $\begin{array}{l}\text { Medical observation } \\
\text { period }\end{array}$ & Fatigue with fever & Tong et al. (2020), Wang et al. (2020f) \\
\hline $\begin{array}{l}\text { FangfengTongsheng pill (FFTS) - 防风通 } \\
\text { 圣丸 }\end{array}$ & $\begin{array}{l}\text { Medical observation } \\
\text { period }\end{array}$ & Fatigue with fever & Wang et al. (2020f) \\
\hline $\begin{array}{l}\text { QingfeiPaidu decoction (QFPD) - 清肺排 } \\
\text { 毒汤 }\end{array}$ & $\begin{array}{l}\text { Clinical treatment } \\
\text { period }\end{array}$ & $\begin{array}{l}\text { Clinical treatment period mild, general, and } \\
\text { severe cases }\end{array}$ & $\begin{array}{l}\text { Du et al. (2020), Ren et al. (2020), Wang et al. (2020f), } \\
\text { Zhang et al. (2020b) }\end{array}$ \\
\hline Suhexiang pill (SHX) - 苏合香丸 & $\begin{array}{l}\text { Clinical treatment } \\
\text { period }\end{array}$ & $\begin{array}{l}\text { Clinical treatment period mild, general, and } \\
\text { severe cases }\end{array}$ & Luo et al. (2020), Wang et al. (2020f) \\
\hline $\begin{array}{l}\text { AngongNiuhuang pill (AGNH) - 安宫牛 } \\
\text { 黄丸 }\end{array}$ & $\begin{array}{l}\text { Clinical treatment } \\
\text { period }\end{array}$ & Several cases and critical cases & Luo et al. (2020), Wang et al. (2020f) \\
\hline Xuebijing injection (XBJ) - 血必净注射液 & $\begin{array}{l}\text { Clinical treatment } \\
\text { period }\end{array}$ & Several cases and critical cases & Luo et al. (2020), Tong et al. (2020), Wang et al. (2020f) \\
\hline
\end{tabular}

TCM controls cardiovascular risk factors such as hypertension and diabetes (Hao et al., 2017). Although attention should be paid to the possible adverse effects of TCM, the benefits of TCM in the treatment of COVID-19 are also obvious (Gray and Belessis, 2020; An et al., 2021; Ren et al., 2021). So far, the integration of TCM and Western medicine is effective for COVID based on previous pharmacological studies (Chen and Chen, 2020; Ni et al., 2020; Xu and Zhang, 2020).

\section{Effects of Combining Drug Therapy on Cardiovascular System}

A combination of drugs can on one hand be beneficial and on the other hand harmful because of side effects. Lopinavir and ritonavir are metabolized by CYP3A and interact with a variety of antiarrhythmic drugs, such as amiodarone and digoxin, which can increase the risk of adverse cardiovascular events. Antiviral drugs such as ritonavir can interact with nonvitamin K-dependent oral antiplatelet agents such as clopidogrel. The combination of ribavirin and IFN- $\alpha$ may aggravate the dysfunction of vascular endothelial cells caused by the virus (Schmidt et al., 2020). Therefore, the combination of ribavirin and IFN- $\alpha$ is not recommended for the treatment of COVID-19 infection. Chloroquine is primarily metabolized by the kidney and should not be combined with inhibitors of CYP1A1, CYP2D6, and CYP3A4 such as lopinavir/ritonavir. There are drug interactions between arbidol and CYP3A4 inhibitors or inducers, and long-term use of arbidol and CYP3A4 inhibitors or inducers can lead to cardiac toxicity (Liu et al., 2009). Tocilizumab can alter lipid metabolism and should not be combined with lopinavir/ ritonavir (Gabay et al., 2016). Generally, it is not recommended to use three or more antiviral drugs at the same time. In case of intolerable adverse effects, the relevant drugs should be stopped (NHC, 2020a).

\section{Other Treatments and Therapeutic Schedules}

Inappropriate use of antibacterials, especially the combination of three or more broad-spectrum antibacterial drugs should be avoided in patients with COVID-19 infection because that there were many complications such as hypertension, hyperglycemia, fever, dry cough, and dyspnea (Yang et al., 2020). Although corticosteroids have the action to reduce the severity of myocarditis and cytokine storm in COVID19 patients, they inhibit viral RNA clearance. Therefore, it recommends using COVID-19 patients with severe symptoms (Ling et al., 2020; Russell et al., 2020). In addition, the intravenous transplantation of mesenchymal stem cells (MSC) can improve the condition of patients with COVID-19, especially for critical cases (Leng et al., 2020). It specifically demonstrated that increased peripheral lymphocytes and IL-10, decreased C-reactive protein and TNF- $\alpha$, and disappear of the overactivated cytokine-secreting immune cells, such as CXCR3+CD4+ T cells, CXCR3+CD8+ T cells, and CXCR3 + NK cells, after MSC treatment compared to those in the placebo control group. The principles of treatment in severe and critical cases include symptomatic treatment, prevention of complications and secondary infections, treatment of underlying diseases, and timely maintenance of organ function. The main measures of organ function support are respiratory support (oxygen therapy and mechanical ventilation), circulatory support (liquid balance strategy, improvement of blood circulation with hemodynamic monitoring), and renal replacement therapy in patients with renal dysfunction, plasma therapy from convalescent patients, and blood purification (plasma exchange, adsorption, perfusion, filtration) (NHC, 2020b). 


\section{PERSPECTIVE}

Once COVID-19 patients are treated, medical personnel must pay attention to baseline cardiovascular health and adjust the treatment plan in time according to changes in heart rate, blood pressure, blood lipids, cardiac function, and electrocardiogram. Medical staff should also take note of drug-drug interactions to avoid drug-induced myocardial injury. In addition, indexes of myocardial injury and cardiac function should be monitored by combining laboratory and imaging results. Clinicians need to continue to assess the efficacy of combination drugs. Combining of three or more antiviral drugs is not recommended, especially in elderly patients. Although progress has been made in the search for drugs to treat infection, a reliable drug screening model in vitro and in vivo should be built with collaborative innovation.

\section{REFERENCES}

Abbvie (2020). Kaletra Prescribing Information. Available from www.rxabbvie. com/pdf/kaletratabpi.pdf. (Accessed May 12, 2020).

Abbvie (2012). KALETRA-lopinavir and ritonavir tablet, film coated. Maryland: DailyMed. 2012-10-10, Available on 2020-05-12 https://dailymed.nlm.nih.gov/ dailymed/drugInfo.cfm?setid=3fa34341-1dce-4bad-b97e-f466e96a0bbe.

Agarwal, A., Mukherjee, A., Kumar, G., Chatterjee, P., Bhatnagar, T., and Malhotra, P. (2020). Convalescent plasma in the management of moderate covid-19 in adults in India: open label phase II multicentre randomised controlled trial (PLACID Trial). BMJ 371, m3939. doi:10.1136/bmj.m3939

Aggarwal, G., Henry, B. M., Aggarwal, S., and Bangalore, S. (2020). Cardiovascular Safety of Potential Drugs for the Treatment of Coronavirus Disease 2019. Am. J. Cardiol 128, 147-150. doi:10.1016/j.amjcard.2020.04.054

Ahmed, M. H., and Hassan, A. (2020). Dexamethasone for the Treatment of Coronavirus Disease (COVID-19): a Review. SN Compr. Clin. Med., 1-10. doi:10.1007/s42399-020-00610-8

Aid, M., Busman-Sahay, K., Vidal, S. J., Maliga, Z., Bondoc, S., Starke, C., et al. (2020). Vascular Disease and Thrombosis in SARS-CoV-2-Infected Rhesus Macaques. Cell 183 (5), 1354-1366. el3. doi:10.1016/j.cell.2020.10.005

Akca, U. K., Kesici, S., Ozsurekci, Y., Aykan, H. H., Batu, E. D., Atalay, E., et al. (2020). Kawasaki-like disease in children with COVID-19. Rheumatol. Int. 40 (12), 2105-2115. doi:10.1007/s00296-020-04701-6

Akhmerov, A., and Marbán, E. (2020). COVID-19 and the Heart. Circ. Res. 126, 1443-1455. doi:10.1161/CIRCRESAHA.120.317055

Alattar, R., Ibrahim, T. B. H., Shaar, S. H., Abdalla, S., Shukri, K., Daghfal, J. N., et al. (2020). Tocilizumab for the treatment of severe coronavirus disease 2019. J. Med. Virol. 92 (10), 2042-2049. doi:10.1002/jmv.25964

Alizargar, J. (2020). The novel coronavirus (COVID-19) and the risk of Kawasaki disease in children. J. Formos. Med. Assoc. 119 (11), 1713-1714. doi:10.1016/ j.jfma.2020.05.030

Aminjafari, A., and Ghasemi, S. (2020). The possible of immunotherapy for COVID-19: A systematic review. Int. Immunopharmacol. 83, 106455. doi:10.1016/j.intimp.2020.106455

An, X., Zhang, Y., Duan, L., Jin, D., Zhao, S., Zhou, R., et al. (2021). The direct evidence and mechanism of traditional Chinese medicine treatment of COVID19. Biomed. Pharmacother. 137, 111267. doi:10.1016/j.biopha.2021.111267

Aouba, A., Baldolli, A., Geffray, L., Verdon, R., Bergot, E., Martin-Silva, N., et al. (2020). Targeting the inflammatory cascade with anakinra in moderate to severe COVID-19 pneumonia: case series. Ann. Rheum. Dis. 79 (10), 1381-1382. doi:10.1136/annrheumdis-2020-217706

Badiou, S., Merle De Boever, C., Dupuy, A. M., Baillat, V., Cristol, J. P., and Reynes, J. (2003). Decrease in LDL size in HIV-positive adults before and after lopinavir/ritonavir-containing regimen: an index of atherogenicity? Atherosclerosis 168 (1), 107-113. doi:10.1016/S0021-9150(03)00058-3

\section{AUTHOR CONTRIBUTIONS}

DL and XZ generated the concept for this review, performed the literature search, and contributed equally to this work. ZD, FL, JM, and XW revised the draft. DL and XW guided the study. All authors have read and approved the final manuscript.

\section{FUNDING}

The study was funded by Natural Science Foundation of He'nan Province of China (202300410313), the Postdoctoral Science Foundation of China (2020M683183), and the Scientific Research Foundation of Xinxiang Medical University (BSKYZZ201628, 300/ 505186 and BSKYZZ201706, 300/505233), the National Natural Science Foundation of China (81873459 and U1804166).

Bansal, M. (2020). Cardiovascular disease and COVID-19. Diabetes Metab. Syndr. 14 (3), 247-250. doi:10.1016/j.dsx.2020.03.013

Barison, A., Aimo, A., Castiglione, V., Arzilli, C., Lupon, J., Codina, P., et al. (2020). Cardiovascular disease and COVID-19: les liaisons dangereuses. Eur. J. Prev. Cardiol. 27 (10), 1017-1025. doi:10.1177/2047487320924501

Becker, R. C. (2020). COVID-19 update: Covid-19-associated coagulopathy. J. Thromb. Thrombolysis 50 (1), 54-67. doi:10.1007/s11239-020-02134-3

Beigel, J. H., Tomashek, K. M., Dodd, L. E., Mehta, A. K., Zingman, B. S., Kalil, A. C., et al. (2020). Remdesivir for the Treatment of Covid-19 - Final Report. $N$. Engl. J. Med. 383 (19), 1813-1826. doi:10.1056/NEJMoa2007764

Beigel, J. H., Bao, Y., Beeler, J., Manosuthi, W., Slandzicki, A., Dar, S. M., et al. (2017). Oseltamivir, amantadine, and ribavirin combination antiviral therapy versus oseltamivir monotherapy for the treatment of influenza: a multicentre, double-blind, randomised phase 2 trial. Lancet Infect. Dis. 17 (12), 1255-1265. doi:10.1016/S1473-3099(17)30476-0

Bertocchi, I., Foglietta, F., Collotta, D., Eva, C., Brancaleone, V., Thiemermann, C., et al. (2020). The hidden role of NLRP3 inflammasome in obesity-related COVID-19 exacerbations: Lessons for drug repurposing. Br. J. Pharmacol. 177 (21), 4921-4930. doi:10.1111/bph.15229

Bikdeli, B., Madhavan, M. V., Jimenez, D., Chuich, T., Dreyfus, I., Driggin, E., et al. (2020). COVID-19 and Thrombotic or Thromboembolic Disease: Implications for Prevention, Antithrombotic Therapy, and Follow-Up: JACC State-of-theArt Review. J. Am. Coll. Cardiol. 75 (23), 2950-2973. doi:10.1016/ j.jacc. 2020.04.031

Bilia, S., Giannini, D., Rizzelli, G. M. L., and Tavoni, A. (2020). Anakinra in COVID-19 therapy: what have we learned from adult-onset Still's disease? Clin. Exp. Rheumatol. 38 (3), 579.

Blaising, J., Polyak, S. J., and Pécheur, E. (2014). Arbidol as a broad-spectrum antiviral: An update. Antivir. Res. 107, 84-94. doi:10.1016/ j.antiviral.2014.04.006

Blanco-Melo, D., Nilsson-Payant, B. E., Liu, W., Uhl, S., Hoagland, D., Møller, R., et al. (2020). Imbalanced Host Response to SARS-CoV-2 Drives Development of COVID-19. Cell 181 (5), 1036-1045.e9. doi:10.1016/j.cell.2020.04.026

Bloch, E. M. (2020). Convalescent plasma to treat COVID-19. Blood 136 (6), 654-655. doi:10.1182/blood.2020007714

Bloch, E. M., Shoham, S., Casadevall, A., Sachais, B. S., Shaz, B., Winters, J. L., et al. (2020). Deployment of convalescent plasma for the prevention and treatment of COVID-19. J. Clin. Invest. 130 (6), 2757-2765. doi:10.1172/JCI138745

Boriskin, Y. S., Leneva, I. A., Pecheur, E. I., and Polyak, S. J. (2008). Arbidol: A Broad-Spectrum Antiviral Compound that Blocks Viral Fusion. Curr. Med. Chem. 15 (10), 997-1005. doi:10.2174/092986708784049658

Bozzi, G., Mangioni, D., Minoia, F., Aliberti, S., Grasselli, G., Barbetta, L., et al. (2021). Anakinra combined with methylprednisolone in patients with severe COVID-19 pneumonia and hyperinflammation: An observational cohort study. J. Allergy Clin. Immunol. 147 (2), 561-566. e4. doi:10.1016/ j.jaci.2020.11.006 
Brojakowska, A., Narula, J., Shimony, R., and Bander, J. (2020). Clinical Implications of SARS-Cov2 Interaction with Renin Angiotensin System. J. Am. Coll. Cardiol 75 (24), 3085-3095. doi:10.1016/j.jacc.2020.04.028

Brown, S. M., Peltan, I., Kumar, N., Leither, L., Webb, B. J., Starr, N., et al. (2020). Hydroxychloroquine vs. Azithromycin for Hospitalized Patients with COVID19 (HAHPS): Results of a Randomized, Active Comparator Trial. Ann. Am. Thorac. Soc. 18 (4), 590-597. doi:10.1513/AnnalsATS.202008-940OC

Buie, J. J., Renaud, L. L., Muise-Helmericks, R., and Oates, J. C. (2017). IFN- $\alpha$ negatively regulates the expression of endothelial nitric oxide synthase and nitric oxide production: implications for systemic lupus erythematosus. J. Immunol. 199 (6), 1979-1988. doi:10.4049/jimmunol.1600108

Caldeira, D., Rodrigues, F. B., Duarte, M. M., Sterrantino, C., Barra, M., Gonçalves, N., et al. (2018). Cardiac Harms of Sofosbuvir: Systematic Review and MetaAnalysis. Drug Saf. 41 (1), 77-86. doi:10.1007/s40264-017-0586-2

Cantini, F., Niccoli, L., Matarrese, D., Nicastri, E., Stobbione, P., and Goletti, D. (2020a). Baricitinib therapy in COVID-19: A pilot study on safety and clinical impact. J. Infect. 81 (2), 318-356. doi:10.1016/j.jinf.2020.04.017

Cantini, F., Niccoli, L., Nannini, C., Matarrese, D., Natale, M., Lotti, P., et al. (2020b). Beneficial impact of Baricitinib in COVID-19 moderate pneumonia; multicentre study. J. Infect. 81 (4), 647-679. doi:10.1016/j.jinf.2020.06.052

Cao, B., Wang, Y., Wen, D., Liu, W., Wang, J., Fan, G., et al. (2020). A Trial of Lopinavir-Ritonavir in Adults Hospitalized with Severe Covid-19. New Engl. J. Med. 382 (19), 1787-1799. doi:10.1056/NEJMoa2001282

Casadevall, A., and Pirofski, L. A. (2020). The convalescent sera option for containing COVID-19. J. Clin. Invest. 130 (4), 1545-1548. doi:10.1172/ JCI138003

Castagné, B., Viprey, M., Martin, J., Schott, A., Cucherat, M., and Soubrier, M. (2019). Cardiovascular safety of tocilizumab: A systematic review and network meta-analysis. PLoS One 14 (8), e0220178. doi:10.1371/journal.pone.0220178

Cauchois, R., Koubi, M., Delarbre, D., Manet, C., Carvelli, J., Blasco, V. B., et al. (2020). Early IL-1 receptor blockade in severe inflammatory respiratory failure complicating COVID-19. Proc. Natl. Acad. Sci. U S A. 117 (32), 18951-18953. doi:10.1073/pnas.2009017117

Cavalcanti, A. B., Zampieri, F. G., Rosa, R. G., Azevedo, L., Veiga, V. C., Avezum, A., et al. (2020). Hydroxychloroquine with or without Azithromycin in Mild-toModerate Covid-19. N. Engl. J. Med. 383 (21), e119. doi:10.1056/ NEJMoa2019014

Cavalli, G., De Luca, G., Campochiaro, C., Della-Torre, E., Ripa, M., Canetti, D., et al. (2020). Interleukin-1 blockade with high-dose anakinra in patients with COVID-19, acute respiratory distress syndrome, and hyperinflammation: a retrospective cohort study. Lancet Rheumatol. 2 (6), e325-e331. doi:10.1016/ S2665-9913(20)30127-2

CDC (2020b). Information for Clinicians on Investigational Therapeutics for Patients with COVID-19. Available from: https://www.cdc.gov/coronavirus/ 2019-ncov/hcp/therapeutic-options.html. (Updated on December 4, 2020).

CDC (2020a). The Novel Coronavirus Pneumonia Emergency Response Epidemiology Team. Vital Surveillances: The Epidemiological Characteristics of an Outbreak of 2019 Novel Coronavirus Diseases (COVID-19)-China, 2020. China CDC Weekly 2 (8), 113-122.

Chen, K., and Chen, H. (2020). Traditional Chinese medicine for combating COVID-19. Front. Med. 14 (5), 529-532. doi:10.1007/s11684-020-0802-9

Chen, L., Xiong, J., Bao, L., and Shi, Y. (2020). Convalescent plasma as a potential therapy for COVID-19. Lancet Infect. Dis. 20 (4), 398-400. doi:10.1016/S14733099(20)30141-9

Chen, Y., Liu, Q., and Guo, D. (2020). Emerging coronaviruses: Genome structure, replication, and pathogenesis. J. Med. Virol. 92, 418-423. doi:10.1002/ jmv.2568110.1002/jmv.26234

Chung, C. J., Nazif, T. M., Wolbinski, M., Hakemi, E., Lebehn, M., Brandwein, R., et al. (2020). Restructuring Structural Heart Disease Practice during the COVID-19 Pandemic: JACC Review Topic of the Week. J. Am. Coll. Cardiol. 75 (23), 2974-2983. doi:10.1016/j.jacc.2020.04.009

Clerkin, K. J., Fried, J. A., Raikhelkar, J., Sayer, G., Griffin, J. M., Masoumi, A., et al. (2020). Coronavirus Disease 2019 (COVID-19) and Cardiovascular Disease. $\begin{array}{lllll}\text { Circulation } & 141 & \text { (20), } & \text { 1648-1655. doi:10.1161/ }\end{array}$ CIRCULATIONAHA.120.046941

Cui, C., Zhang, M., Yao, X., Tu, S., Hou, Z., Jie En, V. S., et al. (2020). Dose selection of chloroquine phosphate for treatment of COVID-19 based on a physiologically based pharmacokinetic model. Acta Pharmaceutica Sinica B 10 (7), 1216-1227. doi:10.1016/j.apsb.2020.04.007

De Spiegeleer, A., Bronselaer, A., Teo, J. T., Byttebier, G., De Tré, G., Belmans, L., et al. (2020). The Effects of ARBs, ACEis, and Statins on Clinical Outcomes of COVID-19 Infection Among Nursing Home Residents. J. Am. Med. Dir. Assoc. 21 (7), 909-914. doi:10.1016/j.jamda.2020.06.018e2

Deng, L., Li, C., Zeng, Q., Liu, X., Li, X., Zhang, H., et al. (2020). Arbidol combined with LPV/r versus LPV/r alone against Corona Virus Disease 2019: A retrospective cohort study. J. Infect. 81 (1), e1-e5. doi:10.1016/j.jinf.2020.03.002

Dong, E., Du, H., and Gardner, L. (2020). An interactive web-based dashboard to track COVID-19 in real time. Lancet Infect. Dis. 20 (5), 533-534. doi:10.1016/ S1473-3099(20)30120-1

Dos Santos, W. G. (2020). Natural history of COVID-19 and current knowledge on treatment therapeutic options. Biomed. Pharmacother. 129, 110493. doi:10.1016/j.biopha.2020.110493

Driggin, E., Madhavan, M. V., Bikdeli, B., Chuich, T., Laracy, J., Biondi-Zoccai, G., et al. (2020). Cardiovascular Considerations for Patients, Health Care Workers, and Health Systems during the COVID-19 Pandemic. J. Am. Coll. Cardiol. 75 (18), 2352-2371. doi:10.1016/j.jacc.2020.03.031

Du, H., Hou, X., Miao, Y., Huang, B., and Liu, D. (2020). Traditional Chinese Medicine: an effective treatment for 2019 novel coronavirus pneumonia (NCP). Chin. J. Nat. Medicines 18 (3), 206-210. doi:10.1016/S1875-5364(20) 30022-4

Duan, K., Liu, B., Li, C., Zhang, H., Yu, T., Qu, J., et al. (2020). Effectiveness of convalescent plasma therapy in severe COVID-19 patients. Proc. Natl. Acad. Sci. U S A. 117 (17), 9490-9496. doi:10.1073/pnas.2004168117

Elfiky, A. A. (2020b). Anti-HCV, nucleotide inhibitors, repurposing against COVID-19. Life Sci. 248, 117477. doi:10.1016/j.lfs.2020.117477

Elfiky, A. A. (2020a). Ribavirin, Remdesivir, Sofosbuvir, Galidesivir, and Tenofovir against SARS-CoV-2 RNA dependent RNA polymerase (RdRp): A molecular docking study. Life Sci. 253, 117592. doi:10.1016/j.lfs.2020.117592

Fan, B. E., Ng, J., Chan, S., Christopher, D., Tso, A., Ling, L. M., et al. (2020). COVID-19 associated coagulopathy in critically ill patients: A hypercoagulable state demonstrated by parameters of haemostasis and clot waveform analysis. J. Thromb. Thrombolysis 51 (3), 663-674. doi:10.1007/s11239-020-02318-x

Fan, Q., Zhang, B., Ma, J., and Zhang, S. (2020). Safety profile of the antiviral drug remdesivir: An update. Biomed. Pharmacother. 130, 110532. doi:10.1016/ j.biopha.2020.110532

Favalli, E. G., Biggioggero, M., Maioli, G., and Caporali, R. (2020). Baricitinib for COVID-19: a suitable treatment? Lancet Infect. Dis. 20 (9), 1012-1013. doi:10.1016/S1473-3099(20)30262-0

Ferner, R. E., and Aronson, J. K. (2020). Chloroquine and hydroxychloroquine in covid-19. BMJ 369, m1432. doi:10.1136/bmj.m1432

Ferrari, R., Di Pasquale, G., and Rapezzi, C. (2020). Commentary: What is the relationship between Covid-19 and cardiovascular disease? Int. J. Cardiol. 310, 167-168. doi:10.1016/j.ijcard.2020.03.074

Fosbol, E. L., Butt, J. H., Ostergaard, L., Andersson, C., Selmer, C., Kragholm, K., et al. (2020). Association of Angiotensin-Converting Enzyme Inhibitor or Angiotensin Receptor Blocker Use with COVID-19 Diagnosis and Mortality. JAMA 324 (2), 168-177. doi:10.1001/jama.2020.11301

Freeman, T. L., and Swartz, T. H. (2020). Targeting the NLRP3 Inflammasome in Severe COVID-19. Front. Immunol. 11, 1518. doi:10.3389/fimmu.2020.01518

Fu, B., Xu, X., and Wei, H. (2020). Why tocilizumab could be an effective treatment for severe COVID-19? J. Transl. Med. 18 (1), 164. doi:10.1186/s12967-02002339-3

Gabay, C., Mclnnes, I. B., Kavanaugh, A., Tuckwell, K., Klearman, M., Pulley, J., et al. (2016). Comparison of lipid and lipid-associated cardiovascular risk marker changes after treatment with tocilizumab or adalimumab in patients with rheumatoid arthritis. Ann. Rheum. Dis. 75 (10), 1806-1812. doi:10.1136/ annrheumdis-2015-207872

Gao, Y., Yan, L., Huang, Y., Liu, F., Zhao, Y., Cao, L., et al. (2020). Structure of the RNA-dependent RNA polymerase from COVID-19 virus. Science. 368(6492), 779-782. doi: DOI: doi:10.1126/science.abb7498

Garibaldi, B. T., Wang, K., Robinson, M. L., Zeger, S. L., Roche, K. B., Wang, M. C., et al. (2020). Effectiveness of remdesivir with and without dexamethasone in hospitalized patients with COVID-19. medRxiv. doi:10.1101/ 2020.11.19.20234153 
Geleris, J., Sun, Y., Platt, J., Zucker, J., Baldwin, M., Hripcsak, G., et al. (2020). Observational Study of Hydroxychloroquine in Hospitalized Patients with Covid-19. New Engl. J. Med. 382 (25), 2411-2418. doi:10.1056/NEJMoa2012410

Gerard, A., Romani, S., Fresse, A., Viard, D., Parassol, N., Granvuillemin, A., et al. (2020). Off-label" use of hydroxychloroquine, azithromycin, lopinavir-ritonavir and chloroquine in COVID-19: A survey of cardiac adverse drug reactions by the French Network of Pharmacovigilance Centers. Therapie 75 (4), 371-379. doi:10.1016/j.therap.2020.05.002

Giustino, G., Croft, L. B., Stefanini, G. G., Bragato, R., Silbiger, J. J., Vicenzi, M., et al. (2020). Characterization of Myocardial Injury in Patients with COVID-19. J. Am. Coll. Cardiol. 76 (18), 2043-2055. doi:10.1016/j.jacc.2020.08.069

Gray, P. E., and Belessis, Y. (2020). The use of Traditional Chinese Medicines to treat SARS-CoV-2 may cause more harm than good. Pharmacol. Res. 156, 104776. doi:10.1016/j.phrs.2020.104776

Gubitosa, J. C., Kakar, P., Gerula, C., Nossa, H., Finkel, D., Wong, K., et al. (2020). Marked Sinus Bradycardia Associated with Remdesivir in COVID-19: A Case and Literature Review. JACC Case Rep. 2 (14), 2260-2264. doi:10.1016/ j.jaccas.2020.08.025

Gupta, A. K., Parker, B. M., Priyadarshi, V., and Parker, J. (2020). Cardiac Adverse Events with Remdesivir in COVID-19 Infection. Cureus 12 (10), e11132. doi:10.7759/cureus.11132

Guzik, T., Mohiddin, S., Dimarco, A., Patel, V., Savvatis, K., Marelli-Berg, F., et al. (2020). COVID-19 and the cardiovascular system: implications for risk assessment, diagnosis, and treatment options. Cardiovasc. Res. 116 (10), 1666-1687. doi:10.1093/cvr/cvaa106

Haigh, K., Syrimi, Z. J., Irvine, S., Blanchard, T. J., Pervaiz, M. S., Toth, A. G., et al. (2020). Hyperinflammation with COVID-19: The key to patient deterioration? Clin. Infect. Pract. 7, 100033. doi:10.1016/j.clinpr.2020.100033

Hamid, S., Mir, M. Y., and Rohela, G. K. (2020). Novel coronavirus disease (COVID-19): a pandemic (epidemiology, pathogenesis and potential therapeutics). New Microbes and New Infections 35, 100679. doi:10.1016/ j.nmni.2020.100679

Han, Y. (2020). Initial COVID-19 affecting cardiac patients in China. Eur. Heart J. 41, 1719. doi:10.1093/eurheartj/ehaa257

Hao, P., Jiang, F., Cheng, J., and Zhao, Y. (2017). Traditional Chinese Medicine for Cardiovascular Disease. J. Am. Coll. Cardiol. 69 (24), 2952-2966. doi:10.1016/ j.jacc.2017.04.041

Hariramnile, S., Nile, A., Qiu, J., Lin, L., Jia, X., and Kai, G. (2020). COVID-19: Pathogenesis, cytokine storm and therapeutic potential of interferons. Cytokine Growth F. R. doi:10.1016/j.cytogfr.2020.05.002

Hasan, S. S., Kow, C. S., Hadi, M. A., Zaidi, S., and Merchant, H. A. (2020). Mortality and Disease Severity Among COVID-19 Patients Receiving ReninAngiotensin System Inhibitors: A Systematic Review and Meta-analysis. Am. J. Cardiovasc. Drugs 20 (6), 571-590. doi:10.1007/s40256-020-00439-5

Hermine, O., Mariette, X., Tharaux, P. L., Resche-Rigon, M., Porcher, R., and Ravaud, P.CORIMUNO-19 Collaborative Group (2021). Effect of Tocilizumab vs Usual Care in Adults Hospitalized with COVID-19 and Moderate or Severe Pneumonia: A Randomized Clinical Trial. JAMA Intern. Med. 181 (1), 32-40. doi:10.1001/jamainternmed.2020.6820

Horby, P., Lim, W. S., Emberson, J. R., Mafham, M., Bell, J. L., Linsell, L., et al. (2020). Dexamethasone in Hospitalized Patients with Covid-19 - Preliminary Report. N. Engl. J. Med. 384 (8), 693-704. doi:10.1056/NEJMoa2021436

Hossen, M. S., Barek, M. A., Jahan, N., and Safiqul Islam, M. (2020). A Review on Current Repurposing Drugs for the Treatment of COVID-19: Reality and Challenges. SN Compr. Clin. Med., 1-13. doi:10.1007/s42399-020-00485-9

Hsu, K. S., Zhao, X., and Cheng, X. (2017). Dual regulation of Statl and Stat 3 by the tumor suppressor protein PML contributes to interferon $\alpha$-mediated inhibition of angiogenesis. J. Biol. Chem. 292 (24), 10048-10060. doi:10.1074/ jbc.M116.771071

Huang, C., Wang, Y., Li, X., Ren, L., Zhao, J., Hu, Y., et al. (2020). Clinical features of patients infected with 2019 novel coronavirus in Wuhan, China. The Lancet 395 (10223), 497-506. doi:10.1016/S0140-6736(20)30183-5

Huet, T., Beaussier, H., Voisin, O., Jouveshomme, S., Dauriat, G., Lazareth, I., et al. (2020). Anakinra for severe forms of COVID-19: a cohort study. Lancet Rheumatol. 2 (7), e393-e400. doi:10.1016/S2665-9913(20)30164-8

Hung, I. F., Lung, K., Tso, E. Y., Liu, R., Chung, T. W., Chu, M., et al. (2020). Triple combination of interferon beta-1b, lopinavir-ritonavir, and ribavirin in the treatment of patients admitted to hospital with COVID-19: an open-label, randomised, phase 2 trial. The Lancet 395 (10238), 1695-1704. doi:10.1016/ S0140-6736(20)31042-4

Inglis, S. C., Naismith, C., White, K., Hendriks, J. M., Bray, J., Hickman, L. D., et al. (2020). CSANZ COVID-19 Cardiovascular Nursing Care Consensus Statement: Executive Summary. Heart Lung Circ. 29 (9), 1263-1267. doi:10.1016/j.hlc.2020.08.001

Jamilloux, Y., Henry, T., Belot, A., Viel, S., Fauter, M., El Jammal, T., et al. (2020). Should we stimulate or suppress immune responses in COVID-19? Cytokine and anti-cytokine interventions. Autoimmun. Rev. 19 (7), 102567. doi:10.1016/ j.autrev.2020.102567

Jankelson, L., Karam, G., Becker, M. L., Chinitz, L. A., and Tsai, M. (2020). QT prolongation, torsades de pointes and sudden death with short courses of chloroquine or hydroxychloroquine as used in COVID-19: a systematic review. Heart Rhythm 17 (9), 1472--1479. doi:10.1016/j.hrthm.2020.05.008

Jo, Y., Jamieson, L., Edoka, I., Long, L., Silal, S., Pulliam, J., et al. (2021). Costeffectiveness of Remdesivir and Dexamethasone for COVID-19 Treatment in South Africa. Open Forum Infect. Dis. 8 (3), ofab040. doi:10.1093/ofid/ofab040

Johns Hopkins University (2021). COVID-19 Global Map in COVID-19 dashboard by the CSSE at JHU COVID-19 Resource Center. Available from https://coronavirus.jhu.edu/map.html.

Johnson, R. M., and Vinetz, J. M. (2020). Dexamethasone in the management of covid -19. BMJ 370, m2648. doi:10.1136/bmj.m2648

Joyner, M. J., Bruno, K. A., Klassen, S. A., Kunze, K. L., Johnson, P. W., Lesser, E. R., et al. (2020). Safety Update: COVID-19 Convalescent Plasma in 20,000 Hospitalized Patients. Mayo Clin. Proc. 95 (9), 1888-1897. doi:10.1016/ j.mayocp.2020.06.028

Kalil, A. C., Patterson, T. F., Mehta, A. K., Tomashek, K. M., Wolfe, C. R., Ghazaryan, V., et al. (2021). Baricitinib plus Remdesivir for Hospitalized Adults with Covid-19. N. Engl. J. Med. 384 (9), 795-807. doi:10.1056/NEJMoa2031994

Kang, Y., Chen, T., Mui, D., Ferrari, V., Jagasia, D., Scherrer-Crosbie, M., et al. (2020). Cardiovascular manifestations and treatment considerations in COVID-19. Heart 106 (15), 1132-1141. doi:10.1136/heartjnl-2020-317056

Katz, J. N., Sinha, S. S., Alviar, C. L., Dudzinski, D. M., Gage, A., Brusca, S. B., et al. (2020). Disruptive Modifications to Cardiac Critical Care Delivery during the Covid-19 Pandemic: An International Perspective. J. Am. Coll. Cardiol. 76 (1), 72-84. doi:10.1016/j.jacc.2020.04.029

Khiali, S., Khani, E., and Entezari-Maleki, T. (2020). A Comprehensive Review on Tocilizumab in COVID-19 Acute Respiratory Distress Syndrome. J. Clin. Pharmacol. 60 (9), 1131-1146. doi:10.1002/jcph.1693

Kissler, S. M., Tedijanto, C., Goldstein, E., Grad, Y. H., and Lipsitch, M. (2020). Projecting the transmission dynamics of SARS-CoV-2 through the postpandemic period. Science 368 (6493), 860-868. doi:10.1126/science.abb5793

Klassen, S. A., Senefeld, J. W., Johnson, P. W., Carter, R. E., Wiggins, C. C., Shoham, S., et al. (2021). Evidence favoring the efficacy of convalescent plasma for COVID-19 therapy. medRxiv. doi:10.1101/2020.07.29.20162917

Kooistra, E. J., Waalders, N. J. B., Grondman, I., Janssen, N. A. F., de Nooijer, A. H., Netea, M. G., et al. (2020). Anakinra Treatment in Critically ill COVID-19 Patients: A Prospective Cohort Study. Crit. Care 24 (1), 688. doi:10.1186/ s13054-020-03364-w

Kunutsor, S. K., and Laukkanen, J. A. (2020). Cardiovascular complications in COVID-19: A systematic review and meta-analysis. J. Infect. 81 (2), e139-e141. doi:10.1016/j.jinf.2020.05.068

Kuo, C., Yang, S., Tsai, Y., Hsieh, C., Liao, W., Chen, L., et al. (2018). Long-acting $\beta 2$-adrenoreceptor agonists suppress type 1 interferon expression in human plasmacytoid dendritic cells via epigenetic regulation. Pulm. Pharmacol. Ther. 48, 37-45. doi:10.1016/j.pupt.2017.10.004

Lafeuillade, A., Hittinger, G., and Chadapaud, S. (2001). Increased mitochondrial toxicity with ribavirin in HIV/HCV coinfection. The Lancet 357 (9252), 280-281. doi:10.1016/S0140-6736(00)03618-7

Lala, A., Johnson, K. W., Januzzi, J. L., Russak, A. J., Paranjpe, I., Richter, F., et al. (2020). Prevalence and Impact of Myocardial Injury in Patients Hospitalized with COVID-19 Infection. J. Am. Coll. Cardiol. 76 (5), 533-546. doi:10.1016/ j.jacc.2020.06.007

Lang, J. P., Wang, X., Moura, F. A., Siddiqi, H. K., Morrow, D. A., and Bohula, E. A. (2020). A current review of COVID-19 for the cardiovascular specialist. Am. Heart J. 226, 29-44. doi:10.1016/j.ahj.2020.04.025

Langer-Gould, A., Smith, J. B., Gonzales, E. G., Castillo, R. D., Figueroa, J. G., Ramanathan, A., et al. (2020). Early identification of COVID-19 cytokine storm 
and treatment with anakinra or tocilizumab. Int. J. Infect. Dis. 99, 291-297. doi:10.1016/j.ijid.2020.07.081

Ledford, H. (2020). Chloroquine hype is derailing the search for coronavirus treatments. Nature 580 (7805), 573. doi:10.1038/d41586-020-01165-3

Lee, K. C. H., Sewa, D. W., and Phua, G. C. (2020). Potential role of statins in COVID-19. Int. J. Infect. Dis. 96, 615-617. doi:10.1016/j.ijid.2020.05.115

Leng, Z., Zhu, R., Hou, W., Feng, Y., Yang, Y., Han, Q., et al. (2020). Transplantation of ACE2- Mesenchymal Stem Cells Improves the Outcome of Patients with COVID-19 Pneumonia. Aging Dis. 11 (2), 216-228. doi:10.14336/AD.2020.0228

Lester, M., Sahin, A., and Pasyar, A. (2020). The use of dexamethasone in the treatment of COVID-19. Ann. Med. Surg. (Lond). 56, 218-219. doi:10.1016/ j.amsu.2020.07.004

Li, B., Yang, J., Zhao, F., Zhi, L., Wang, X., Liu, L., et al. (2020). Prevalence and impact of cardiovascular metabolic diseases on COVID-19 in China. Clin. Res. Cardiol. 109 (5), 531-538. doi:10.1007/s00392-020-01626-9

Li, G., and De Clercq, E. (2020). Therapeutic options for the 2019 novel coronavirus (2019-nCoV). Nat. Rev. Drug Discov. 19 (3), 149-150. doi:10.1038/d41573-020-00016-0

Li, L., Zhang, W., Hu, Y., Tong, X., Zheng, S., Yang, J., et al. (2020d). Effect of Convalescent Plasma Therapy on Time to Clinical Improvement in Patients with Severe and Life-threatening COVID-19: A Randomized Clinical Trial. JAMA 324 (5), 460-470. doi:10.1001/jama.2020.10044

Li, R., Hou, Y., Huang, J., Pan, W., Ma, Q., Shi, Y., et al. (2020b). Lianhuaqingwen exerts anti-viral and anti-inflammatory activity against novel coronavirus (SARS-CoV-2). Pharmacol. Res. 156, 104761.

Li, X., Guan, B., Su, T., Liu, W., Chen, M., Bin, W. K., et al. (2020a). Impact of cardiovascular disease and cardiac injury on in-hospital mortality in patients with COVID-19: a systematic review and meta-analysis. Heart 106 (15), 1142-1147. doi:10.1136/heartjnl-2020-317062

Li, Y., Xie, Z., Lin, W., Cai, W., Wen, C., and Yujuanet, al. (2020c). An exploratory randomized, controlled study on the efficacy and safety of lopinavir/ritonavir or arbidol treating adult patients hospitalized with mild/moderate COVID-19 (ELACOI). MedRxiv. Available from: https://www.medrxiv.org/content/ medrxiv/early/2020/03/23/2020.03.19.20038984.full.pdf. (Accessed May 15, 2020). doi:10.1101/2020.03.19.20038984

Lim, M. A., and Pranata, R. (2020). Worrying situation regarding the use of dexamethasone for COVID-19. Ther. Adv. Respir. Dis. 14, 1753466620942131. doi:10.1177/1753466620942131

Ling, Y., Xu, S., and Lin, Y. (2020). Persistence and clearance of viral RNA in 2019 novel coronavirus disease rehabilitation patients. Chin. Med. J. 133 (00), E007. doi:10.1097/CM9.0000000000000774

Liu, D., Li, X., Zhang, Y., Kwong, J. S., Li, L., Zhang, Y., et al. (2018). Chloroquine and hydroxychloroquine are associated with reduced cardiovascular risk: a systematic review and meta-analysis. Drug Des. Dev. Ther. 2018 (12), 1685-1695. doi:10.2147/DDDT.S166893

Liu, D., Zeng, X., Li, X., Cui, C., Hou, R., Guo, Z., et al. (2020a). Advances in the molecular mechanisms of NLRP3 inflammasome activators and inacativators. Biochem. Pharmacol. 175, 113863. doi:10.1016/j.bcp.2020.113863

Liu, D., Zeng, X., Li, X., Mehta, J. L., and Wang, X. (2018). Role of NLRP3 inflammasome in the pathogenesis of cardiovascular diseases. Basic Res. Cardiol. 113 (1), 5. doi:10.1007/s00395-017-0663-9

Liu, J., Cao, R., Xu, M., Wang, X., Zhang, H., Hu, H., et al. (2020b). Hydroxychloroquine, a less toxic derivative of chloroquine, is effective in inhibiting SARS-CoV-2 infection in vitro. Cel Discov. 6 (1), 16. doi:10.1038/ s41421-020-0156-0

Liu, L. (2020c). Traditional Chinese medicine contributes to the treatment of COVID-19 patients. Chin. Herbal Medicines 12 (2), 95-96. doi:10.1016/ j.chmed.2020.04.003

Liu, M., Wang, S., Yao, W., Wu, H., Meng, S., and Wei, M. (2009). Pharmacokinetic properties and bioequivalence of two formulations of arbidol: An open-label, single-dose, randomized-sequence, two-period crossover study in healthy Chinese male volunteers. Clin. Ther. 31 (4), 784-792. doi:10.1016/ j.clinthera.2009.04.016

Liu, P. P., Blet, A., Smyth, D., and Li, H. (2020d). The Science Underlying COVID19: Implications for the Cardiovascular System. Circulation 142 (1), 68-78. doi:10.1161/CIRCULATIONAHA.120.047549
Liu, S., Lin, H. M., Baine, I., Wajnberg, A., Gumprecht, J. P., Rahman, F., et al. (2020e). Convalescent plasma treatment of severe COVID-19: a propensity score-matched control study. Nat. Med. 26 (11), 1708-1713. doi:10.1038/ s41591-020-1088-9

Liu, X., Long, C., Xiong, Q., Chen, C., Ma, J., Su, Y., et al. (2020f). Association of angiotensin converting enzyme inhibitors and angiotensin II receptor blockers with risk of COVID-19, inflammation level, severity, and death in patients with COVID-19: A rapid systematic review and meta-analysis. Clin. Cardiol. doi:10.1002/clc.23421

Liu, Y., Yang, Y., Zhang, C., Huang, F., Wang, F., Yuan, J., et al. (2020g). Clinical and biochemical indexes from 2019-nCoV infected patients linked to viral loads and lung injury. Sci. China (Life Sciences) 63 (03), 364-374. doi:10.1007/s11427020-1643-8

Long, B., Brady, W. J., Koyfman, A., and Gottlieb, M. (2020). Cardiovascular complications in COVID-19. Am. J. Emerg. Med. 38 (7), 1504-1507. doi:10.1016/j.ajem.2020.04.048

Lu, Q., Zhang, S., Cui, N., Hu, J., Fan, Y., Guo, C., et al. (2015). Common adverse events associated with ribavirin therapy for Severe Fever with Thrombocytopenia Syndrome. Antivir. Res. 119, 19-22. doi:10.1016/ j.antiviral.2015.04.006

Lumpuy-Castillo, J., Lorenzo-Almoros, A., Pello-Lazaro, A. M., Sanchez-Ferrer, C., Egido, J., Tunon, J., et al. (2020). Cardiovascular Damage in COVID-19: Therapeutic Approaches Targeting the Renin-Angiotensin-Aldosterone System. Int. J. Mol. Sci. 21 (18). doi:10.3390/ijms21186471

Luo, L., Jiang, J., Wang, C., Fitzgerald, M., Hu, W., Zhou, Y., et al. (2020). Analysis on herbal medicines utilized for treatment of COVID-19. Acta Pharmaceutica Sinica B. doi:10.1016/j.apsb.2020.05.007

Luo, P., Liu, Y., Qiu, L., Liu, X., Liu, D., and Li, J. (2020). Tocilizumab treatment in COVID-19: A single center experience. J. Med. Virol. doi:10.1002/jmv.25801

Ma, Y. J., Du, L. Y., Yan, L. B., Liao, J., Cheng, X., Xie, W. W., et al. (2020). Longterm follow-up of HCV patients with sustained virological response after treatment with pegylated interferon plus ribavirin. Hepatobiliary Pancreat. Dis. Int. 20, 137-141. doi:10.1016/j.hbpd.2020.02.004

Madjid, M., Safavi-Naeini, P., Solomon, S. D., and Vardeny, O. (2020). Potential Effects of Coronaviruses on the Cardiovascular System: A Review. JAMA Cardiol. 5 (7), 831-840. doi:10.1001/jamacardio.2020.1286

Magro, G. (2020). COVID-19: Review on latest available drugs and therapies against SARS-CoV-2. Coagulation and inflammation cross-talking. Virus. Res. 286, 198070. doi:10.1016/j.virusres.2020.198070

Mahmud, E., Dauerman, H. L., Welt, F. G., Messenger, J. C., Rao, S. V., Grines, C., et al. (2020). Management of Acute Myocardial Infarction during the COVID19 Pandemic. J. Am. Coll. Cardiol. 76 (11), 1375-1384. doi:10.1016/ j.jacc.2020.04.039

Maleszewski, J. J., Young, P. M., Ackerman, M. J., and Halushka, M. K. (2020). An Urgent Need for Studies of the Late Effects of SARS-CoV-2 on the Cardiovascular System. Circulation 143 (13), 1271-1273. doi:10.1161/ CIRCULATIONAHA.120.051362

Manjaly Thomas, Z. R., Leuppi-Taegtmeyer, A., Jamiolkowski, D., Steveling-Klein, E., Bellutti-Enders, F., Scherer Hofmeier, K., et al. (2020). Emerging Treatments in COVID-19: Adverse Drug Reactions Including Drug Hypersensitivities. J. Allergy. Clin. Immunol. 146 (4), 786-789. doi:10.1016/j.jaci.2020.07.008

Mantlo, E., Bukreyeva, N., Maruyama, J., Paessler, S., and Huang, C. (2020). Antiviral activities of type I interferons to SARS-CoV-2 infection. Antivir. Res. 179, 104811. doi:10.1016/j.antiviral.2020.104811

Markham, A. (2017). Baricitinib: First Global Approval. Drugs 77 (6), 697-704. doi:10.1007/s40265-017-0723-3

Matsushita, K., Marchandot, B., Jesel, L., Ohlmann, P., and Morel, O. (2020). Impact of COVID-19 on the Cardiovascular System: A Review. J. Clin. Med. 9 (5). doi:10.3390/jcm 9051407

Matthay, M. A., and Thompson, B. T. (2020). Dexamethasone in hospitalised patients with COVID-19: addressing uncertainties. Lancet Respir. Med. 8 (12), 1170-1172. doi:10.1016/S2213-2600(20)30503-8

Mehta, N., Kalra, A., Nowacki, A. S., Anjewierden, S., Han, Z., Bhat, P., et al. (2020). Association of Use of Angiotensin-Converting Enzyme Inhibitors and Angiotensin II Receptor Blockers with Testing Positive for Coronavirus Disease 2019 (COVID-19). JAMA Cardiol. 5 (9), 1020-1026. doi:10.1001/ jamacardio.2020.1855 
Mercuro, N. J., Yen, C. F., Shim, D. J., Maher, T. R., Mccoy, C. M., Zimetbaum, P. J., et al. (2020). Risk of QT Interval Prolongation Associated with Use of Hydroxychloroquine with or without Concomitant Azithromycin Among Hospitalized Patients Testing Positive for Coronavirus Disease 2019 (COVID-19). JAMA Cardiol. 5 (9), 1036-1041. doi:10.1001/ jamacardio.2020.1834

Morena, V., Milazzo, L., Oreni, L., Bestetti, G., Fossali, T., Bassoli, C., et al. (2020). Off-label use of tocilizumab for the treatment of SARS-CoV-2 pneumonia in Milan, Italy. Eur. J. Intern. Med. 76, 36-42. doi:10.1016/j.ejim.2020.05.011

Mubagwa, K. (2020). Cardiac effects and toxicity of chloroquine: a short update. Int. J. Antimicrob. Agents 56 (2), 106057. doi:10.1016/j.ijantimicag.2020.106057

Muhovic, D., Bojovic, J., Bulatovic, A., Vukcevic, B., Ratkovic, M., Lazovic, R., et al. (2020). First case of drug-induced liver injury associated with the use of tocilizumab in a patient with COVID-19. Liver Int. doi:10.1111/liv.14516

Mulangu, S., Dodd, L. E., Davey, R. T., Mbaya, O. T., and Proschan, M. (2019). A Randomized, Controlled Trial of Ebola Virus Disease Therapeutics. New Engl. J. Med. 381, 2293-2303. doi:10.1056/NEJMoa1910993

Muller, M. P., Dresser, L., Raboud, J., Mcgeer, A., Rea, E., Richardson, S. E., et al. (2007). Adverse events associated with high-dose ribavirin: evidence from the Toronto outbreak of severe acute respiratory syndrome. Pharmacotherapy 27 (4), 494-503. doi:10.1592/phco.27.4.494

Nägele, M. P., Haubner, B., Tanner, F. C., Ruschitzka, F., and Flammer, A. J. (2020). Endothelial dysfunction in COVID-19: Current findings and therapeutic implications. Atherosclerosis 314, 58-62. doi:10.1016/ j.atherosclerosis.2020.10.014

Navarro-Millán, I., Sattui, S. E., Lakhanpal, A., Zisa, D., Siegel, C. H., and Crow, M. K. (2020). Use of Anakinra to Prevent Mechanical Ventilation in Severe COVID-19: A Case Series. Arthritis Rheumatol. 72 (12), 1990-1997. doi:10.1002/art.41422

Nelson, C. P., Schunkert, H., Samani, N. J., and Erridge, C. (2015). Genetic Analysis of Leukocyte Type-I Interferon Production and Risk of Coronary Artery Disease. Arterioscler Thromb. Vasc. Biol. 35, 1456-1462. doi:10.1161/ ATVBAHA.114.304925

NHC (2020a). National Health Commission of the People's Republic of China: Guideline on diagnosis and treatment of COVID-19 (Trial 6th edition). Available fromin Chinese) http://www.nhc.gov.cn/xcs/zhengcwj/202002/ 8334a8326dd94d329df351d7da8aefc2.shtml (Accessed May 16, 2020).

NHC (2020b). National Health Commission of the People's Republic of China: Notice on novel coronavirus pneumonia diagnosis and treatment plan (Trial version 7). Available fromin Chinese) http://www.nhc.gov.cn/yzygj/s7653p/ 202003/46c9294a7dfe4cef80dc7f5912eb1989.shtml. (Accessed May 16, 2020).

Ni, L., Yuan, W., Chen, L., Han, C., Zhang, H., Luan, X., et al. (2020). Combating COVID-19 with integrated traditional Chinese and Western medicine in China. Acta Pharmaceutica Sinica B 10 (7), 1149-1162. doi:10.1016/j.apsb.2020.06.009

Nih (2021). COVID-19 Treatment Guidelines. Therapeutic Management of Adults With COVID-19. Available from: https://www.covid19treatmentguidelines.nih. gov/therapeutic-management/ (Updated on February 11, 2021).

Nishiga, M., Wang, D. W., Han, Y., Lewis, D. B., and Wu, J. C. (2020). COVID-19 and cardiovascular disease: from basic mechanisms to clinical perspectives. Nat. Rev. Cardiol. 17 (9), 543-558. doi:10.1038/s41569-020-0413-9

Oldfield, V., and Plosker, G. L. (2006). Lopinavir/ritonavir: a review of its use in the management of HIV infection. Drugs 66 (9), 1275-1299. doi:10.2165/ 00003495-200666090-00012

Panigada, M., Bottino, N., Tagliabue, P., Grasselli, G., Novembrino, C., Chantarangkul, V., et al. (2020). Hypercoagulability of COVID-19 patients in intensive care unit: A report of thromboelastography findings and other parameters of hemostasis. J. Thromb. Haemost. 18 (7), 1738-1742. doi:10.1111/ jth. 14850

Paniri, A., and Akhavan-Niaki, H. (2020). Emerging role of IL-6 and NLRP3 inflammasome as potential therapeutic targets to combat COVID-19: Role of IncRNAs in cytokine storm modulation. Life Sci. 257, 118114. doi:10.1016/ j.lfs.2020.118114

Pareek, A., Purkait, I., Mehta, R. T., and Grover, A. (2018). Metabolic and cardiovascular benefits of hydroxychloroquine: exploration in a wider population at high CV risk. Ann. Rheum. Dis. 77 (9), e59. doi:10.1136/ annrheumdis-2017-212499

Pasin, L., Cavalli, G., Navalesi, P., Sella, N., Landoni, G., Yavorovskiy, A. G., et al. (2021). Anakinra for patients with COVID-19: a meta-analysis of non- randomized cohort studies. Eur. J. Intern. Med. 86, 34-40. doi:10.1016/ j.ejim.2021.01.016

Patel, S. K., Saikumar, G., Rana, J., Dhama, J., Yatoo, M. I., Tiwari, R., et al. (2020). Dexamethasone: A boon for critically ill COVID-19 patients? Trav. Med Infect Dis. 37, 101844. doi:10.1016/j.tmaid.2020.101844

Pathak, E. B. (2020). Convalescent plasma is ineffective for covid-19. BMJ 371, m4072. doi:10.1136/bmj.m4072

Pichler, W. J. (2006). Adverse side-effects to biological agents. Allergy 61, 912-920. doi:10.1111/j.1398-9995.2006.01058.x

Pillaiyar, T., Meenakshisundaram, S., and Manickam, M. (2020). Recent discovery and development of inhibitors targeting coronaviruses. Drug Discov. Today 25 (4), 668-688. doi:10.1016/j.drudis.2020.01.015

Prescott, H. C., and Rice, T. W. (2020). Corticosteroids in COVID-19 ARDS: Evidence and Hope during the Pandemic. JAMA 324 (13), 1292-1295. doi:10.1001/jama.2020.16747

Qiu, P., Zhou, Y., Wang, F., Wang, H., Zhang, M., Pan, X., et al. (2020). Clinical characteristics, laboratory outcome characteristics, comorbidities, and complications of related COVID-19 deceased: a systematic review and meta-analysis. Aging Clin. Exp. Res. 32( (9), 1869-1878. doi:10.1007/s40520020-01664-3

Rabaan, A. A., Al-Ahmed, S. H., Haque, S., Sah, R., Tiwari, R., Malik, Y. S., et al. (2020). SARS-CoV-2, SARS-CoV, and MERS-COV: A comparative overview. Infez Med. 28 (2), 174-184.

Rempenault, C., Combe, B., Barnetche, T., Gaujoux-Viala, C., Lukas, C., Morel, J., et al. (2018). Metabolic and cardiovascular benefits of hydroxychloroquine in patients with rheumatoid arthritis: a systematic review and meta-analysis. Ann. Rheum. Dis. 77 (1), 98-103. doi:10.1136/annrheumdis-2017-211836

Ren, J., Zhang, A., and Wang, X. (2020). Traditional Chinese medicine for COVID19 treatment. Pharmacol. Res. 155, 104743. doi:10.1016/j.phrs.2020.104743

Ren, W., Liang, P., Ma, Y., Sun, Q., Pu, Q., Dong, L., et al. (2021). Research progress of traditional Chinese medicine against COVID-19. Biomed. Pharmacother. 137, 111310. doi:10.1016/j.biopha.2021.111310

Reyskens, K., Fisher, T., Schisler, J., Connor, W. G. O., Rogers, A. B., Willis, M. S., et al. (2013). Cardio-metabolic effectsof HIV protease inhibitors (lopinavir/ ritonavir). PLoS One 8 (11), e73347. doi:10.1371/journal.pone.0073347

Richardson, P., Griffin, I., Tucker, C., Smith, D., Oechsle, O., Phelan, A., et al. (2020). Baricitinib as potential treatment for 2019-nCoV acute respiratory disease. Lancet 395 (10223), e30-e31. doi:10.1016/S0140-6736(20)30304-4

Roback, J. D., and Guarner, J. (2020). Convalescent Plasma to Treat COVID-19: Possibilities and Challenges. JAMA 323 (16), 1561-1562. doi:10.1001/ jama.2020.4940

Rogers, R., Shehadeh, F., Mylona, E. K., Rich, J., Neill, M., Touzard-Romo, F., et al. (2020). Convalescent plasma for patients with severe COVID-19: a matched cohort study. Clin. Infect. Dis. 73 (1), e208-e214. doi:10.1093/cid/ ciaa 1548

Rome, B. N., and Avorn, J. (2020). Drug Evaluation during the Covid-19 Pandemic. New Engl. J. Med. 382 (24), 2282-2284. doi:10.1056/NEJMp2009457

Rosenberg, E. S., Dufort, E. M., Udo, T., Wilberschied, L. A., Kumar, J., Tesoriero, J., et al. (2020). Association of Treatment with Hydroxychloroquine or Azithromycin with In-Hospital Mortality in Patients with COVID-19 in New York State. JAMA 323 (24), 2493-2502. doi:10.1001/jama.2020.8630

Ruscitti, P., Berardicurti, O., Iagnocco, A., and Giacomelli, R. (2020). Cytokine storm syndrome in severe COVID-19. Autoimmun. Rev. 19 (7), 102562. doi:10.1016/j.autrev.2020.102562

Russell, C., Millar, J., and Baillie, J. (2020). Clinical evidence does not support corticosteroid treatment for 2019-nCoV lung injury. The Lancet 395 (10223), 473-475. doi:10.1016/S0140-6736(20)30317-2

Sallard, E., Lescure, F. X., Yazdanpanah, Y., Mentre, F., and Smadja, N. P. (2020). Type 1 interferons as a potential treatment against COVID-19. Antivir. Res. 178, 104791. doi:10.1016/j.antiviral.2020.104791

Salvi, R., and Patankar, P. (2020). Emerging pharmacotherapies for COVID-19. Biomed. Pharmacother. 128, 110267. doi:10.1016/j.biopha.2020.110267

Sanfilippo, F., La Rosa, V., Oliveri, F., and Astuto, M. (2021). COVID-19, Hypercoagulability, and Cautiousness with Convalescent Plasma. Am. J. Respir. Crit. Care Med. 203 (2), 257-258. doi:10.1164/rccm.2020083139LE

Savarino, A., Boelaert, J. R., Cassone, A., Majori, G., and Cauda, R. (2003). Effects of chloroquine on viral infections: an old drug against today's 
diseases. Lancet Infect. Dis. 3 (11), 722-727. doi:10.1016/S1473-3099(03) 00806-5

Sayad, B., Sobhani, M., and Khodarahmi, R. (2020). Sofosbuvir as Repurposed Antiviral Drug against COVID-19: Why Were We Convinced to Evaluate the Drug in a Registered/Approved Clinical Trial? Arch. Med. Res. 51 (6), 577-581. doi:10.1016/j.arcmed.2020.04.018

Schmidt, F. P., Zimmermann, T., Wenz, T., Schnorbus, B., Ostad, M. A., Feist, C., et al. (2020). Interferon- and ribavirin-free therapy with new direct acting antivirals (DAA) for chronic hepatitis C improves vascular endothelial function. Int. J. Cardiol. 271, 296-300. doi:10.1016/j.ijcard.2018.04.058

Schrezenmeier, E., and Dörner, T. (2020). Mechanisms of action of hydroxychloroquine and chloroquine: implications for rheumatology. Nat. Rev. Rheumatol. 16 (3), 155-166. doi:10.1038/s41584-020-0372-x

Shah, S., Das, S., Jain, A., Misra, D. P., and Negi, V. S. (2020). A systematic review of the prophylactic role of chloroquine and hydroxychloroquine in coronavirus disease-19 (COVID-19). Int. J. Rheum. Dis. 23 (5), 613-619. doi:10.1111/1756$185 \mathrm{X} .13842$

Sharma, S. (2020). COVID-19: A Concern for Cardiovascular Disease Patients. Cardiovasc. Toxicol. 20 (5), 443-447. doi:10.1007/s12012-020-09596-0

Sharun, K., Tiwari, R., Dhama, J., and Dhama, K. (2020). Dexamethasone to combat cytokine storm in COVID-19: Clinical trials and preliminary evidence. Int. J. Surg. 82, 179-181. doi:10.1016/j.ijsu.2020.08.038

Shen, C., Wang, Z., Zhao, F., Yang, Y., Li, J., Yuan, J., et al. (2020). Treatment of 5 Critically Ill Patients with COVID-19 with Convalescent Plasma. JAMA 323 (16), 1582-1589. doi:10.1001/jama.2020.4783

Shereen, M. A., Khan, S., Kazmi, A., Bashir, N., and Siddique, R. (2020). COVID-19 infection: Origin, transmission, and characteristics of human coronaviruses. J. Adv. Res. 24, 91-98. doi:10.1016/j.jare.2020.03.005

Simonovich, V. A., Burgos, P. L., Scibona, P., Beruto, M. V., Vallone, M. G., Vazquez, C., et al. (2021). A Randomized Trial of Convalescent Plasma in Covid-19 Severe Pneumonia. N. Engl. J. Med. 384 (7), 619-629. doi:10.1056/ NEJMoa2031304

Sleijfer, S., Bannink, M., Van Gool, A. R., Kruit, W. H. J., and Stoter, G. (2005). Side Effects of Interferon- $\alpha$ Therapy. Pharm. World Sci. 27 (6), 423. doi:10.1007/ s11096-005-1319-7

Spinner, C. D., Gottlieb, R. L., Criner, G. J., Arribas, L. J., Cattelan, A. M., Soriano, V. A., et al. (2020). Effect of Remdesivir vs Standard Care on Clinical Status at 11 Days in Patients with Moderate COVID-19: A Randomized Clinical Trial. JAMA 324 (11), 1048-1057. doi:10.1001/jama.2020.16349

Stebbing, J., Phelan, A., Griffin, I., Tucker, C., Oechsle, O., Smith, D., et al. (2020). COVID-19: combining antiviral and anti-inflammatory treatments. Lancet Infect. Dis. 20 (4), 400-402. doi:10.1016/S1473-3099(20)30132-8

Sterne, J., Murthy, S., Diaz, J. V., Slutsky, A. S., Villar, J., Angus, D. C., et al. (2020). Association between Administration of Systemic Corticosteroids and Mortality Among Critically Ill Patients with COVID-19: A Meta-analysis. JAMA 324 (13), 1330-1341. doi:10.1001/jama.2020.17023

Tetlow, S., Segiet-Swiecicka, A., O'Sullivan, R., O’Halloran, S., Kalb, K., BrathwaiteShirley, C., et al. (2021). ACE inhibitors, angiotensin receptor blockers and endothelial injury in COVID-19. J. Intern. Med. 289 (5), 688-699. doi:10.1111/ joim. 13202

Tiberghien, P., de Lamballerie, X., Morel, P., Gallian, P., Lacombe, K., and Yazdanpanah, Y. (2020). Collecting and evaluating convalescent plasma for COVID-19 treatment: why and how? Vox Sang 115 (6), 488-494. doi:10.1111/ vox. 12926

Tong, T., Wu, Y. Q., Ni, W. J., Shen, A. Z., and Liu, S. (2020). The potential insights of Traditional Chinese Medicine on treatment of COVID-19. Chin. Med. 15, 51. doi:10.1186/s13020-020-00326-w

Touafchia, A., Bagheri, H., Carrié, D., Durrieu, G., Sommet, A., Chouchana, L., et al. (2021). Serious bradycardia and remdesivir for coronavirus 2019 (COVID-19): a new safety concerns. Clin. Microbiol. Infect. 27 (5), 791. e5-8. doi:10.1016/j.cmi.2021.02.013

Toubiana, J., Poirault, C., Corsia, A., Bajolle, F., Fourgeaud, J., Angoulvant, F., et al. (2020). Kawasaki-like multisystem inflammatory syndrome in children during the covid-19 pandemic in Paris, France: prospective observational study. BMJ 369, m2094. doi:10.1136/bmj.m2094

Tu, Y. (2016). Artemisinin-A Gift from Traditional Chinese Medicine to the World (Nobel Lecture). Angew. Chem. Int. Ed. Engl. 55 (35), 10210-10226. doi:10.1002/anie.201601967
Vabret, N., Britton, G. J., Gruber, C., Hegde, S., Kim, J., Kuksin, M., et al. (2020). Immunology of COVID-19: current state of the science. Immunity 52 (6), 910-941. doi:10.1016/j.immuni.2020.05.002

Vankadari, N. (2020). Arbidol: A potential antiviral drug for the treatment of SARS-CoV-2 by blocking the trimerization of viral spike glycoprotein? Int. J. Antimicrob. Ag., 105998. doi:10.1016/j.ijantimicag.2020.105998

Varga, Z., Flammer, A. J., Steiger, P., Haberecker, M., Andermatt, R., Zinkernagel, A. S., et al. (2020). Endothelial cell infection and endotheliitis in COVID-19. Lancet 395 (10234), 1417-1418. doi:10.1016/ S0140-6736(20)30937-5

Vetter, P., Kaiser, L., Calmy, A., Agoritsas, T., and Huttner, A. (2020). Dexamethasone and remdesivir: finding method in the COVID-19 madness. Lancet 1 (8), E309-E310. doi:10.1016/S2666-5247(20)30173-7

Wang, B. X., and Fish, E. N. (2020a). Global virus outbreaks: Interferons as 1st responders. Semin. Immunol. 43, 101300. doi:10.1016/j.smim.2019.101300

Wang, J. J., Edin, M. L., Zeldin, D. C., Li, C., Wang, D. W., and Chen, C. (2020b). Good or bad: Application of RAAS inhibitors in COVID-19 patients with cardiovascular comorbidities. Pharmacol. Ther. 215, 107628. doi:10.1016/ j.pharmthera.2020.107628

Wang, M., Cao, R., Zhang, L., Yang, X., Liu, J., Xu, M., et al. (2020c). Remdesivir and chloroquine effectively inhibit the recently emerged novel coronavirus (2019-nCoV) in vitro. Cell Res. 30 (3), 269-271. doi:10.1038/s41422-020-0282-0

Wang, Q., Zhang, Y., Wu, L., Niu, S., Song, C., Zhang, Z., et al. (2020d). Structural and Functional Basis of SARS-CoV-2 Entry by Using Human ACE2. Cell 181 (4), 894-904. doi:10.1016/j.cell.2020.03.045

Wang, X., Cao, R., Zhang, H., Liu, J., Xu, M., Hu, H., et al. (2020e). The antiinfluenza virus drug, arbidol is an efficient inhibitor of SARS-CoV-2 in vitro. Cell Discov. 6, 28. doi:10.1038/s41421-020-0169-8

Wang, Y., Zeng, X., Zhao, Y., Chen, W., and Chen, Y. Z. (2020f). The pros and cons of traditional Chinese medicines in the treatment of COVID-19. Pharmacol. Res. 157, 104873. doi:10.1016/j.phrs.2020.104873

Wang, Y., Zhang, D., Du, G., Du, R., Zhao, J., Jin, Y., et al. (2020g). Remdesivir in adults with severe COVID-19: a randomised, double-blind, placebo-controlled, multicentre trial. Lancet 395 (10236), 1569-1578. doi:10.1016/S0140-6736(20)31022-9

WHO (2021). Coronavirus disease (COVID-2019) situation reports. Coronavirus disease (COVID-19) Weekly Epidemiological Update and Weekly Operational Update. Available from: https://www.who.int/emergencies/diseases/novelcoronavirus-2019/situation-reports. (Accessed April 21, 2021).

WHO (2020). WHO welcomes preliminary results about dexamethasone use in treating critically ill COVID-19 patients. https://www.who.int/news-room/ detail/16-06-2020-who-welcomes-preliminary-results-about-dexamethasoneuse-in-treating-critically-ill-covid-19-patientsJune 18, 2020).2020

Wong, A. (2020). COVID-19 and toxicity from potential treatments: Panacea or poison. Emerg. Med. Australas. 32 (4), 697-699. doi:10.1111/1742-6723.13537

Wu, R., Wang, L., Kuo, H., Shannar, A., Peter, R., Chou, P., et al. (2020). An Update on Current Therapeutic Drugs Treating COVID-19. Curr. Pharmacol. Rep., 1-15. doi:10.1007/s40495-020-00216-7

Xie, F., Yun, H., Levitan, E. B., Muntner, P., and Curtis, J. R. (2019). Tocilizumab and the risk of cardiovascular disease: direct comparison among biologic disease-modifying antirheumatic drugs for rheumatoid arthritis patients. Arthritis Care Res. 71 (8), 1004-1018. doi:10.1002/acr.23737

$\mathrm{Xu}$, J., and Zhang, Y. (2020). Traditional Chinese Medicine treatment of COVID19. Complement. Therapies Clin. Pract. 39, 101165. doi:10.1016/ j.ctcp. 2020.101165

Xu, K., Chen, Y., Yuan, J., Yi, P., Ding, C., Wu, W., et al. (2020). “Clinical Efficacy of Arbidol in Patients with 2019 Novel Coronavirus-Infected Pneumonia: A Retrospective Cohort Study," in The Lancet. Available from https://papers. ssrn.com/sol3/papers.cfm?abstract_id=3542148. (Accessed May 15, 2020).

Xu, X., Han, M., Li, T., Sun, W., Wang, D., Fu, B., et al. (2020). Effective treatment of severe COVID-19 patients with tocilizumab. P. Natl. Acad. Sci. Usa (20), 11710970-11710975. doi:10.1073/pnas.2005615117

Yang, Q., Xie, L., Zhang, W., Zhao, L., Wu, H., Jiang, J., et al. (2020). Analysis of the clinical characteristics, drug treatments and prognoses of 136 patients with coronavirus disease 2019. J. Clin. Pharm. Ther. 45 (4), 609-616. doi:10.1111/ jcpt. 13170

Ye, M., Fu, D., Ren, Y., Wang, F., Wang, D., Zhang, F., et al. (2020). Treatment with convalescent plasma for COVID-19 patients in Wuhan, China. J. Med. Virol. 92 (10), 1890-1901. doi:10.1002/jmv.25882 
Ye, Q., Wang, B., and Mao, J. (2020). The pathogenesis and treatment of the 'Cytokine Storm' in COVID-19. J. Infect. 80 (6), 607-613. doi:10.1016/j.jinf.2020.03.037

Yetman, D., and Vinetz, J. (2021). Current Treatments for COVID-19. Available from: https://www.healthline.com/health/coronavirus-treatment. (Updated on February 18, 2021).

Zhang, J., Litvinova, M., Liang, Y., Wang, Y., Wang, W., and Zhao, S. (2020a). Changes in contact patterns shape the dynamics of the COVID-19 outbreak in China. Science 368 (6498), 1481-1486. doi:10.1126/science.abb8001

Zhang, K. (2020b). Is traditional Chinese medicine useful in the treatment of COVID-19? Am. J. Emerg. Med. 38 (10), 2238. doi:10.1016/j.ajem.2020.03.046

Zhang, L., Lin, D., Sun, X., Curth, U., and Drosten, C. (2020c). Crystal structure of SARS-CoV-2 main protease provides a basis for design of improved alphaketoamide inhibitors. Science 368 (6489), 409-412. doi:10.1126/science.abb3405

Zhang, P., Zhu, L., Cai, J., Lei, F., Qin, J. J., Xie, J., et al. (2020d). Association of Inpatient Use of Angiotensin-Converting Enzyme Inhibitors and Angiotensin II Receptor Blockers with Mortality Among Patients with Hypertension Hospitalized with COVID-19. Circ. Res. 126 (12), 1671-1681. doi:10.1161/ CIRCRESAHA.120.31713410.1161/CIRCRESAHA.120.317242

Zhang, X., Yu, J., Pan, L. Y., and Jiang, H. Y. (2020e). ACEI/ARB use and risk of infection or severity or mortality of COVID-19: A systematic review and metaanalysis. Pharmacol. Res. 158, 104927. doi:10.1016/j.phrs.2020.104927

Zhang, X., Zhang, Y., Qiao, W., Zhang, J., and Qi, Z. (2020f). Baricitinib, a drug with potential effect to prevent SARS-COV-2 from entering target cells and control cytokine storm induced by COVID-19. Int. Immunopharmacol. 86, 106749. doi:10.1016/j.intimp.2020.106749

Zhang, Y., Xu, Q., Sun, Z., and Zhou, L. (2020g). Current targeted therapeutics against COVID-19: Based on first-line experience in China. Pharmacol. Res. 157, 104854. doi:10.1016/j.phrs.2020.104854
Zheng, Y. Y., Ma, Y. T., Zhang, J. Y., and Xie, X. (2020). COVID-19 and the cardiovascular system. Nat. Rev. Cardiol. 17 (5), 259-260. doi:10.1038/s41569-020-0360-5

Zhou, P. (2020). Traditional Chinese medicine. Comb. Chem. High Throughput Screen. 13 (10), 836. doi:10.2174/138620710793360329

Zhou, P., Yang, X., Wang, X., Hu, B., Zhang, L., Zhang, W., et al. (2020). A pneumonia outbreak associated with a new coronavirus of probable bat origin. Nature 579 (7798), 270-273. doi:10.1038/s41586-020-2012-7

Zhu, Z., Lu, Z., Xu, T., Chen, C., Yang, G., Zha, T., et al. (2020). Arbidol monotherapy is superior to lopinavir/ritonavir in treating COVID-19. J. Infect. 81 (1), e21-e23. doi:10.1016/j.jinf.2020.03.060

Conflict of Interest: The authors declare that the research was conducted in the absence of any commercial or financial relationships that could be construed as a potential conflict of interest.

Publisher's Note: All claims expressed in this article are solely those of the authors and do not necessarily represent those of their affiliated organizations, or those of the publisher, the editors and the reviewers. Any product that may be evaluated in this article, or claim that may be made by its manufacturer, is not guaranteed or endorsed by the publisher.

Copyright $\odot 2021$ Liu, Zeng, Ding, Lv, Mehta and Wang. This is an open-access article distributed under the terms of the Creative Commons Attribution License (CC $B Y$ ). The use, distribution or reproduction in other forums is permitted, provided the original author(s) and the copyright owner(s) are credited and that the original publication in this journal is cited, in accordance with accepted academic practice. No use, distribution or reproduction is permitted which does not comply with these terms. 